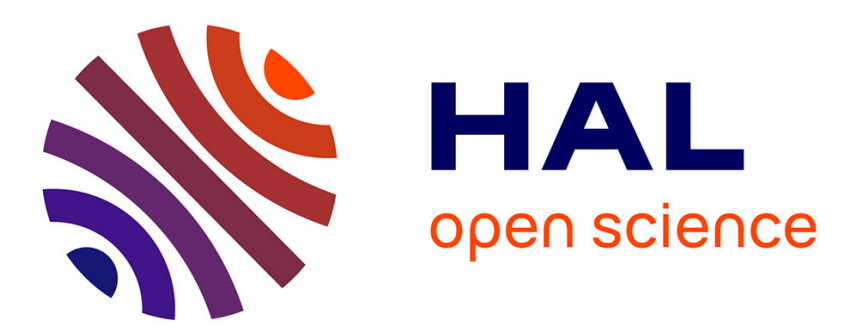

\title{
Geological evolution of Ares Vallis on Mars: Formation by multiple events of catastrophic flooding, glacial and periglacial processes
}

\author{
Andrea Pacifici, Goro Komatsu, Monica Pondrelli
}

\section{- To cite this version:}

Andrea Pacifici, Goro Komatsu, Monica Pondrelli. Geological evolution of Ares Vallis on Mars: Formation by multiple events of catastrophic flooding, glacial and periglacial processes. Icarus, 2009, 202 (1), pp.60. 10.1016/j.icarus.2009.02.029 . hal-00545289

\author{
HAL Id: hal-00545289 \\ https://hal.science/hal-00545289
}

Submitted on 10 Dec 2010

HAL is a multi-disciplinary open access archive for the deposit and dissemination of scientific research documents, whether they are published or not. The documents may come from teaching and research institutions in France or abroad, or from public or private research centers.
L'archive ouverte pluridisciplinaire $\mathbf{H A L}$, est destinée au dépôt et à la diffusion de documents scientifiques de niveau recherche, publiés ou non, émanant des établissements d'enseignement et de recherche français ou étrangers, des laboratoires publics ou privés. 


\section{Accepted Manuscript}

Geological evolution of Ares Vallis on Mars: Formation by multiple events of catastrophic flooding, glacial and periglacial processes

Andrea Pacifici, Goro Komatsu, Monica Pondrelli

PII: $\quad$ S0019-1035(09)00109-2

DOI: $\quad$ 10.1016/j.icarus.2009.02.029

Reference: $\quad$ YICAR 8953

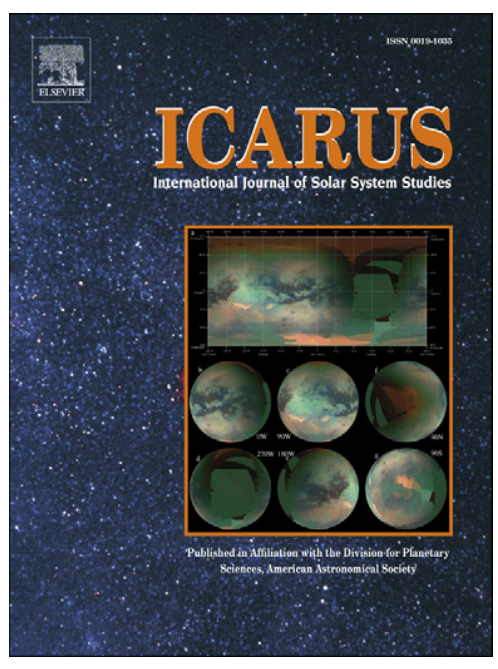

To appear in: Icarus

Received date: 26 March 2008

Revised date: 16 January 2009

Accepted date: 27 February 2009

Please cite this article as: A. Pacifici, G. Komatsu, M. Pondrelli, Geological evolution of Ares Vallis on Mars: Formation by multiple events of catastrophic flooding, glacial and periglacial processes, Icarus (2009), doi: 10.1016/j.icarus.2009.02.029

This is a PDF file of an unedited manuscript that has been accepted for publication. As a service to our customers we are providing this early version of the manuscript. The manuscript will undergo copyediting, typesetting, and review of the resulting proof before it is published in its final form. Please note that during the production process errors may be discovered which could affect the content, and all legal disclaimers that apply to the journal pertain. 
Andrea Pacifici, Goro Komatsu, Monica Pondrelli

5

International Research School of Planetary Sciences

Dipartimento di Scienze

Università d'Annunzio

Viale Pindaro, 42

65127 Pescara

11

Italy

12

Email addresses:

14

A. Pacifici: pacifici@irsps.unich.it

G. Komatsu: goro@irsps.unich.it

Manuscript:

\section{Pages: 50}

Tables: 0 
Geological evolution of Ares Vallis, Mars.

32

33

34 Corresponding author:

35

36

Andrea Pacifici

37

International Research School of Planetary Sciences

Dipartimento di Scienze

Università d'Annunzio

Viale Pindaro, 42 


\section{Abstract}

Ares Vallis is one of the greatest outflow channels of Mars. Using high-resolution images of recent missions to Mars (MGS, 2001 Odyssey, and Mars Express), we investigated Ares Vallis and its valley arms, taking advantage of 3-dimensional analysis performed using the high-resolution stereo capability of the Mars

63 Express High Resolution Stereo Camera (HRSC). In our view, Ares Vallis is characterized by catastrophic

64 flood landscapes partially superimposed by ice-related morphologies. Catastrophic flood landforms include erosional terraces, grooved terrains, streamlined uplands, giant bars, pendant bars, and cataract-like features. Ice-related morphologies include probable kame features, thermokarstic depressions, and patterned grounds. Our investigations outline that throughout the Hesperian age, Ares Vallis and its valley arms had been sculpted by several, time-scattered, catastrophic floods, originating from Iani, Hydaspis and Aram Chaos. Geomorphological evidence suggests that catastrophic floods were ice-covered, and that climatic conditions of Mars at this time were similar to those of the present day. At the end of each catastrophic flood, ice masses grounded, forming a thick stagnant dead-ice body. Each catastrophic flood was followed by a relatively brief period of warmer-wetter climatic conditions, originated as a consequence of catastrophic flooding. During such periods thermokarstic depressions originated, liquid water formed meandering channels, and ice-contact deposits were emplaced by ice-walled streams. Finally, the climate turned into cold-dry conditions similar to the present-day ones, and ice masses sublimated.

Keywords: Mars, surface; Mars, climate; Geological processes; Ices.

\section{1 - Introduction}

Outflow channels on Mars are large complexes of fluid-eroded troughs up to $100 \mathrm{~km}$ wide and 2000

$84 \mathrm{~km}$ long. The flows that formed Martian outflow channels appear to have emanated from discrete collapse zones or chaotic terrains (Baker, 1982). Ares Vallis (fig. 1) is one of the greatest among these: it is a trough 
Ares Vallis has been deeply investigated in the past decades, partially to support landing site

89 analyses of the NASA Pathfinder, which landed near the present termination of Ares Vallis on July 4, 1997.

90 Several geologic interpretations of Ares Vallis have been proposed. Baker and Milton (1974), Baker (1982),

91 Baker et al. (1992), Komatsu and Baker (1997) hypothesize that Ares Vallis was carved by catastrophic

92 floods. Glicken and Schultz (1980) propose that Ares Vallis originated by giant clay-rich volcanic mud

93 flows. Lucchitta et al. (1981) and Lucchitta (1982, 2001) suggest ice-sculpturing processes. Costard (1989)

94 proposes a fluvio-thermal erosion. Robinson et al. (1996) consider that it was formed by glacial processes

95 with some fluvial activity. Marchenko et al. (1998) investigated the mouth of Ares Vallis and interpreted it as

96 shaped by multiple catastrophic flood events. Nelson and Greeley (1999) suggest an initial sheetwash

97 followed by deepening of channels caused by subsequent floodings. Tanaka (1999) propose catastrophic

98 outbreak of water from pressurized aquifers, evolving into debris flows. Furthermore, thermokarstic

99 landforms and processes along Ares Vallis have been reported by some works (Costard and Dollfus, 1986;

100 Costard and Kargel, 1995; Costard and Baker, 2001). Leverington (2004) proposes a volcanic origin. The

101 hypotheses regarding the origin of Martian outflow channels are summarized in Baker et al. (1992) and Carr

102 (1996). Each model of origin and evolution implies different processes of the Ares Vallis formation and

103 different climatic evolutions of Mars. Almost all the proposed models derive from observations carried out

104 using mainly Mariner and Viking data with low-medium spatial resolutions (some tens to few hundreds of

105 meters for each pixel). Aims of this work, therefore, are: i) to investigate Ares Vallis with high-resolution

106 images (HRSC, THEMIS VIS and MOC narrow angle), ii) to describe new observed morphologies, and

107 according to these, iii) to hypothesize new possible scenarios illustrating the geologic history of Ares Vallis.

108 Our observations are based mainly on a detailed geomorphological map of Ares Vallis recently published by

109 Pacifici (2008).

113 The High Resolution Stereo Camera (HRSC), on board the ESA mission Mars Express, provides 114 orthorectified images and stereo-derived Digital Terrain Models (DTMs). The orthorectified images are 115 provided both in gray scale (obtained by nadir channel) and in color (with pan-sharpening of nadir channel). 116 HRSC images fill the gap in cell size between high-resolution small-footprint images (e.g., MGS MOC 
117 narrow angle) and low-resolution large-footprint images (e.g., Viking, Mars Global Surveyor MOC wide

118 angle and Mars Odyssey THEMIS infra-red), over very large areas. Such characteristics of the HRSC images

119 are very helpful in order to observe stratigraphic correlations and wide-ranging, small-scale morphologies.

120 Furthermore, HRSC data allow draping of high-resolution images on stereo-derived DTMs, and their 121 observation in 3-dimensional view.

122 Twenty-one HRSC orbit datasets covering entire Ares Vallis were processed in order to provide 123 images with resolutions between 12.5 and $50 \mathrm{~m} / \mathrm{pixel}$, and derived DTMs with a spatial resolution of about $124200 \mathrm{~m} /$ pixel. We complemented the HRSC datasets with other mission datasets such as Viking, Mars Global 125 Surveyor MOC wide angle (MOC WA), and Mars Odyssey THEMIS (both Visible and IR). MOC narrow 126 angle (MOC NA) images were used to further characterize the observed morphologies with much more 127 details. The Mars Odyssey THEMIS infra-red (THEMIS IR) data were used in order to characterize also 128 thermal properties of surfaces. Regarding thermal properties, we performed only qualitative and not 129 quantitative observations in this work. Finally, Mars Global Surveyor MOLA-megdr grid data were used to 130 conduct regional topographic analysis.

\section{3 - Physiographic and geological setting of Ares Vallis}

134 wide and $1500 \mathrm{~m}$ deep. A few erosional terraces characterize its steep walls and broad, shallow, and anastomosing channels occur on the surrounding plateaus. The lower reach (Wide Ares Vallis) is about 100 $\mathrm{km}$ wide, and it is shallower and wider and its walls are less steep approaching the valley termination.

137 Widths of both the reaches are generally constant and the transition between them is evident.

138 Three valley arms tens of kilometers wide merge with Ares Vallis. We appoint these valleys with the 139 informal names of Eastern Valley, Western Valley, and Aram Chaos Channel (fig. 1). Eastern Valley is a 140 trough about $20 \mathrm{~km}$ wide and $1 \mathrm{~km}$ deep, hanging above Ares Vallis. Similar to Ares Vallis, Eastern Valley 141 originates from Iani Chaos but at a more marginal (eastern) position and higher altitudes. The valley merges 142 into the upper reach of Ares Vallis with a hanging morphology and a difference in altitude of about $600 \mathrm{~m}$.

143 Western Valley is a broad and shallow trough emanating from Hydaspis Chaos and hanging above Ares 144 Vallis. It extends for about $370 \mathrm{~km}$, varies in width from $40 \mathrm{~km}$ to $160 \mathrm{~km}$, and terminates with a hanging 145 morphology with a difference in altitude of about $900 \mathrm{~m}$. Western Valley shows gently-sloping walls and lies 
about $1000 \mathrm{~m}$ below the neighboring plateaus. Aram Chaos Channel is a narrow and deep trough emanating from Aram Chaos and merging with Ares Vallis. Using the term 'the Ares Vallis Complex' we will refer to Ares Vallis and its incoming troughs.

A longitudinal topographic profile of the Ares Vallis floor (fig. 2) shows that the narrower upper reach of Narrow Ares Vallis has a steeper topographic gradient on average. The deepest point of Iani Chaos, which is believed to be one of the main source areas for fluids eroding Ares Vallis (Komatsu and Baker, 1997), lies about $800 \mathrm{~m}$ below the beginning of Narrow Ares Vallis. Floors of Wide Ares Vallis lie about $200 \mathrm{~m}$ above the lowest floors of Narrow Ares Vallis, and its topographic profile appears to be irregular at the upstream portion and flat on the downstream portion. The present-day termination of Ares Vallis consists of a scarp 50-200 m high, which was formed by Tiu-Simud Valles flows postdating Ares Vallis (Marchenko et al., 1998; Nelson and Greeley, 1999; Costard and Baker, 2001).

Regarding ages of Ares Vallis surfaces, Tanaka et al. (2005) map five units in the area. They vary in ages from Middle Noachian to Late Hesperian. Hartmann (2005) also indicates a Late Hesperian age for the Ares Vallis floor and its surroundings. Pacifici (2008) suggests ages varying from Early to Late Hesperian. Werner (2005) observes that ages of the northern reach of Iani Chaos vary from $3.5 \mathrm{Ga}$ to $50 \mathrm{Ma}$, while the upper reach of Ares Vallis shows ages varying from 650 to 40 Ma.

\section{4 - Geomorphological analysis}

We observe in the Ares Vallis Complex two different typologies of geomorphological features. The first one includes grooved terrains, streamlined uplands, giant bars, pendant bars, cataract-like features and hanging valleys, resembling terrestrial morphologies that are believed to have been shaped by catastrophic floods. The second typology includes ice-contact features, thermokarstic depressions, and patterned grounds. These ice-related features overlap and postdate catastrophic flood morphologies. All these features are described below in detail.

\subsection{Catastrophic flood features}

\subsubsection{Erosional terraces and hanging valleys}

Along the upper reach of Ares Vallis, there are terraces (fig. 3) occurring (at least) at five different altitude levels. Each terrace seems to have been sculpted by one (or more) catastrophic flooding, originated 
175 by an enormous release of water emanating from chaotic terrains. A terrace occurring at the highest altitude

176 consists of a very large area extending mainly northeast of Narrow Ares Vallis. This terrace is delineated by

177 the $-2000 \mathrm{~m}$ contour line, and it is characterized by a smooth-texture on medium-resolution images (15-50

$178 \mathrm{~m} /$ pixel). Locally, shallow anastomosing channels occur. This terrace corresponds to the areas produced by

179 the first floods emanating from Iani Chaos. Terraces occurring at lower altitudes mark subsequent floods and

180 illustrate progressive deepening and channelization of Ares Vallis. They develop laterally to the entire widths

181 of Ares Vallis and often show a grooved surface. The grooved surface of the terraces suggests that it was

182 sculpted mainly by erosive processes.

183 Eastern and Western Valley arms are truncated by the Ares Vallis main channel and hang over its

184 floors. Crosscutting relationships among Eastern Valley and the erosional terraces of Ares Vallis show that

185 Eastern Valley originated during the first four catastrophic flood events (fig. 3), and then became abandoned

186 during the subsequent events.

187 Western Valley (fig. 4) is a broad and shallow trough characterized by the absence of erosional

188 terraces. This suggests that Western Valley was formed during one single catastrophic flood emanating from

189 Hydaspis Chaos. If multiple floods indeed occurred, they did not leave any observational evidence.

190 Crosscutting relationships between Western Valley and Ares Vallis suggest that such catastrophic flood

191 event occurred between the second and fourth catastrophic flood events of Ares Vallis.

192 Aram Chaos Channel is a deep and narrow gorge in which erosional terraces are consequently

193 poorly extended. On the base of high-resolution images we hypothesize that Aram Chaos Channel was

194 carved by at least two catastrophic floods (possibly more), which occurred at the same time of last floods

195 emanating from Iani Chaos.

Grooved terrains characterize a large part of Ares Vallis Complex. They occur mainly on top of

200 erosional terraces, and on the valley floors as patches. Grooved terrains occur both at the proximal and at the

201 distal portions of Ares Vallis troughs. Grooves appear to consist of equally-spacing furrows or trenches

202 between narrow ridges (fig. 5a and 5c) that extend along the direction of the flow. They are hundreds of 203 meters wide, hundreds of meters spaced, and about a few to tens of kilometers long. Groove depths are not 
estimated due to their small scales. The overall morphology of such features resembles those of some terrestrial mega-flutes (fig. 5d and 5e). On the base of relationships among grooves and neighboring morphologies it is possible to assess certain morphological and geological properties of the grooved terrains.

207 The grooved terrains appear to be locally etched and postdated by narrow, meandering channels (fig. 6),

208 which typically emanate from flat-floored impact craters or from shallow, flat-floored irregularly-shaped 209 depressions. Comparison between channels and grooves, and their geometrical relationships, allows 210 hypothesizing that grooves are no more than meters or a few tens of meters deep. In areas where water

211 flowed deeper and longer (i.e. on the main stream of Ares Vallis) grooves appear wider and deeper than in 212 areas where water flowed shallower and for shorter time (i.e. Western Valley). Moreover, relationships 213 among meandering channels and grooves seem to indicate that grooved terrains consist of relatively "soft"

214 highly erodible materials. This inference is consistent with the presence of remnants of ancient impact craters 215 that often characterize grooved terrains (fig. 7). Such remnants, commonly with positive relieves, suggest 216 that they consist of rocks more resistant than the surrounding surfaces to the erosive processes shaping 217 grooves. On the topmost part of remnants, grooves generally are absent or less prominent. Relationships 218 among grooves and impact crater remnants, then, seem to confirm that that grooves formed mainly on 219 relatively "soft" highly erodible materials.

\subsubsection{Streamlined uplands}

Streamlined uplands occur both at the origin of Ares Vallis Complex troughs (i.e. in the vicinity of chaotic terrains), and at the terminal reach of Ares Vallis. They seem to have been formed by erosion of

224 former Noachian and Early Hesperian plateau materials. Streamlined uplands are teardrop-shaped, and 225 characterized by a whaleback profile. Their topmost part reaches the same altitude of the neighboring 226 plateaus and consists of Noachian and Early Hesperian terrains (Pacifici, 2008). Usually, terrains 227 surrounding streamlined uplands appear to be grooved.

Streamlined uplands located in the vicinity of chaotic terrains (fig. 8) are the most prominent features

229 occurring near (and sometime in connection with) the flood source areas. Arrangement of such streamlined 230 uplands indicates that they were shaped by broad converging floods coming out from the chaos. Cross231 cutting relationships among troughs separating streamlined uplands seem to indicate that floods abandoned

232 lateral troughs early with respect to the innermost ones. This setting could be consistent with a progressive 
233

234 of floods.

235

Streamlined uplands occurring at the terminal reach of Ares Vallis (fig. 9) show a distribution and orientations suggesting a spreading of floods. The upstream portion of streamlined uplands is commonly characterized by an impact crater or a rocky hill, which is believed to have caused the diversion of flow, protecting downstream Noachian and Early Hesperian plateaus from flood erosion (fig. 10).

\subsubsection{Giant Bars}

We observe a few features occurring in alcoves flanking valley floors on the downstream portion of Narrow Ares Vallis (fig. 11). They appear some kilometers long, a few km wide, and rising for about $500 \mathrm{~m}$ from the valley floor. We propose two hypotheses for the origin of such features. In the first hypothesis we observe that these features appear strikingly similar to giant eddy bars formed during some known terrestrial catastrophic floods in alcoves flanking flooded valleys (Carling et al., 2002). Thus we suggest that such Martian features could have been formed as giant bars during Ares Vallis catastrophic floods. Their thicknesses suggest that catastrophic flood(s) probably responsible for their emplacement was (were) at least $500 \mathrm{~m}$ deep in the narrow reach of Ares Vallis. The origin of the alcove features could be related to exhumation and erosion of buried impact craters by catastrophic floods. These features overlie grooved terrains and are separated from the valley wall by a swath of about $1.5 \mathrm{~km}$. Such separation can be interpreted as a non-deposition zone, which occurs between bedforms and valley walls, and which is interpreted to form by flow separation immediately downstream from a flow expansion or channel bend (Burr et al., 2004). The topmost part of the possible bars is almost flat and lacks grooves. It is possible to identify boulders about $5-10 \mathrm{~m}$ in diameter on the largest pristine impact crater (1.5 $\mathrm{km}$ in diameter) occurring on top of one the possible bar.

In the second hypothesis, we suggest that these features could be interpreted as mass wasting deposits originated by collapsing of Ares Vallis walls, and possibly reworked by following catastrophic floods. However, lacking of erosional features, such as grooves, and occurrence of the flat trough, which characteristically separates this feature from the valley wall, lead us to discard this second idea. 
The term pendant bar was introduced to indicate streamlined mounds emplaced by Missoula floods downstream of bedrock projections in the Channeled Scabland of North America (Baker, 1982). Pendant bars form by sediment deposition in flow separations developing downstream from a flow obstacle. Similar features, kilometers long and hundreds of meters high, occur in the Ares Vallis Complex (fig. 12), mostly at the terminal reach of Ares Vallis. Pendant bars distinguish from streamlined uplands: the former, which are essentially depositional features, develop exclusively downstream of a bedrock projection, and appear noticeably thinner with respect to the bedrock; the latter, which are erosional morphologies, typically lack a bedrock projection on the upstream side (fig. 9b) or, if this occurs, both are about the same thickness (fig. 10).

Using HRSC data, three-dimensional analyses were performed for two pendant bars (fig. 12), which are located in the Ares Vallis terminal reach (fig. 9a). Bedrock knobs occurring upstream of the pendant bars are about $3 \mathrm{~km}$ wide and $4 \mathrm{~km}$ long, and rise for about 500-600 $\mathrm{m}$ with respect to the nearest valley floor. Streamlined deposits forming bars are 20-35 km long, and their topmost parts rise for about $300-400 \mathrm{~m}$. The upstream portion of Pb1 (fig. 12a, 12b) is surrounded by a parabolic-shaped scour, and the adjacent valley floor is extensively grooved. Both upstream parabolic scour and grooved terrain are not observed at the $\mathrm{Pb} 2$ pendant bar (fig. 12c, 12d); the valley floor surrounding $\mathrm{Pb} 2$ consists of a flat deposit characterized by bright, shallow, and elongated hollows observable at the MOC NA resolution.

Our observations suggest that two different phases may have existed during each catastrophic flood event (fig. 12f). In the first phase, flood carved a parabolic scour upstream of bedrock projections and emplaced pendant bars to the downstream. At the same time, flood scoured grooves on the valley floor. The thicknesses of the pendant bars suggest that catastrophic flood in which they formed have a depth of at least about $300 \mathrm{~m}$ at the terminal reach of Ares Vallis. In the second phase during waning stage of catastrophic flood, the decreased strength of the flow led to the deposition of a flat sedimentary field in the inner part of channels, burying both parabolic scours and grooved terrains.

287 However, a majority of boulders should have a smaller size range than can be observed in $1.5 \mathrm{~m} / \mathrm{pixel} \mathrm{MOC}$ 288 NA images (fig. 12e). This boulder size range is similar to that of the largest boulders observed at the 289 Pathfinder Landing site (Golombek et al., 1997), which is located next to the present-day termination of Ares 
Vallis (fig. 9a). This fact could indicate that $1.5 \mathrm{~m}$ likely represents the upper limit of the dimension of clasts

291 transported by Ares Vallis catastrophic floods at least at the terminal reaches and maybe during last floods.

\subsubsection{Cataract-like features}

Abandoned cataracts are impressive erosional forms created during the Missoula catastrophic floods in North America. They were shaped by headwall recessional processes when catastrophic floods crossed a sharp scarp of structural or erosional origin (Baker, 1982). A very similar feature occurs at the Ares Vallis Complex near the junction of a shallow trough emanating from Western Valley and the Ares Vallis main trough (fig. 13). The shallow trough is hanging above both Western Valley and Ares Vallis floors: this suggests that it was carved early during the catastrophic flood event originated by fluids emanating from Hydaspis Chaos, and subsequently abandoned.

The cataract-like feature is an arcuate scarp, $500 \mathrm{~m}$ high and several kilometers wide. It seems to have originated when a catastrophic flood crossed a sharp scarp, and successively extended $35 \mathrm{~km}$ upstream by flood-driven, headwall recessional processes. Unlike terrestrial cataracts, large closed depressions are unobserved at the base of the cataract-like feature of the Ares Vallis Complex. The shallow trough occurring upstream of the cataract-like feature shows an association of grooved terrain, streamlined uplands and pendant bars. In the downstream of the cataract, instead, trough enlarges with a fan-shaped morphology: here grooved terrain and pendant bars are unobserved and only two small streamlined remnants occur.

\subsection{Ice-related morphologies}

\subsubsection{Thermokarstic depressions} well-developed shallow depressions occur inside a large flat-floored impact crater about $90 \mathrm{~km}$ in diameter,

316 Crater (fig. 14). Irregularly-shaped depressions of Eastern Valley Crater are a few kilometers wide, and 317 typically coalescing. The depressions are 50-150 m deep. The deepest ones are coalescing and larger. The 
meters thick (fig. 18). In its medial portion, the crater floor is incised by Eastern Valley. Nearby impact craters and intra-crater terrains do not exhibit shallow and coalescing depressions similar to those occurring within Eastern Valley Crater. This fact leads us to think that the formation of such features does not depend on regional geological and/or climatic events, but relates exclusively to the geological history of Eastern Valley Crater, and to the geological properties of its floor materials.

The shallow and coalescing depressions observed in the Ares Vallis Complex share several morphological similarities with terrestrial thermokarstic depressions, such as alas valleys. Alas valleys are periglacial morphologies that form in permafrost or ice-rich soils. Thawing of ground-ice leads to the formation of thaw lakes, which could coalesce with others and with a stream (Czudek and Demek 1970). Probable alas valleys and other thermokarstic depressions have been already observed and mapped in circum-Chryse outflow channels by some authors (Carr and Shaber, 1977; Costard and Baker, 2001; Costard and Kargel, 1995). Such morphologies are supposed to form on Mars even by localized enhanced sublimation instead of melting processes (Levy et al., 2005). Carr and Shaber (1977) note that characteristics of alas valley on Mars, with respect to terrestrial ones, may indicate a more uniform distribution of ice within the surface materials. This indicates that the ices were deposited contemporarily with the host material.

We hypothesize the following scenario (fig. 14) about the origin of the thermokarstic depressions in Eastern Valley Crater. Catastrophic flood(s) originated from Iani Chaos, etched the Eastern Valley Crater rim, and infilled it with ice-rich deposits. The layering observed in depression walls seems to indicate multiple occurrences of catastrophic flooding, or at least that variations in the flow regime existed. After the flood(s), an ice-rich deposit occupied the Eastern Valley Crater floor. The ice-rich deposit would have subsequently wasted by melting or sublimating processes, leading to the alas-like landscape. The depths of the thermokarstic depressions suggest a thickness of at least $150 \mathrm{~m}$ for the ice-rich deposit.

Eastern Valley incises through the thermokarstic depressions, implying at least two different flood events in the area: the earlier one(s) supplied the stratified ice-rich deposit; the later one(s) eroded it subsequently to the development of the thermokarstic depressions. During the later flood(s), processes of thermal erosion may have played an important role in the reworking of the ice-rich deposit. Thermal erosion causes degradation and removal of ice-rich soils by heat transfer between the water flow and the frozen ground, followed by transport of unfrozen materials (Aguirre-Puente et al., 1994). 

short, and that its development should be considered a short-term event. Calculations of thermal conditions beneath a thermokarst lake in Central Yacutia show that, if the water level is stable or increasing, thaw may reach $30 \mathrm{~m}$ over a period of 200 years. If the ice-wasting processes responsible for the Martian alas-like depressions were dominated by melting rather than sublimation process, development of thermokarstic depressions may have been relatively fast (about some hundreds to a few thousand of years). Harris (2002) observe that a thaw pond, once formed, will go on enlarging in icy materials until it runs out of ground ice or intersect a drainage way. In the same way, it is possible that the last flood(s) through Eastern Valley partially disrupted walls of the alas-like depressions, caused their draining, and then stopped their development. periods characterized by colder-dryer climatic conditions (similar to the present-day Martian climate) in which ice-rich deposits were emplaced, and periods characterized by warmer-wetter climatic conditions in which alas-like features were shaped. The inference about the possible warmer-wetter climatic conditions may be invalid if sublimation rather melting processes dominated the wasting of the ice-rich deposits. Nevertheless, the geomorphological relationship between the alas-like valleys and the present-day Eastern Valley indicates that floods were multiple and well separated in time. catastrophic flood processes. In the narrow upper reach of Ares Vallis, the mesa-like features are flat-topped ridges (fig. 15), a few of kilometers wide, tens of kilometers long, and rising for about 100-200 m. They are slightly sinuous, and elongated parallel to the trough. Locally, the ridges bifurcate and turn around streamlined hills. In the wide lower reach of Ares Vallis (fig. 16), the mesa-like features vary in shape,

372 dimension or orientation. They exhibit forms such as circular, crescent, elongated, reticulated, bifurcating or 373 sinuous. The thickest mesa-like features rise for about $500 \mathrm{~m}$ and occur in the upstream portion of Wide Ares 374 Vallis. Toward the downstream direction, the thickness of the mesa-like features progressively decreases, 375 until it reaches a value of about $100 \mathrm{~m}$ (fig. 2). The topmost portion of the largest mesa-like feature appears 
to be etched by round-shaped, flat-floored depressions, which are consistent with a thermokarstic origin (fig. 16a). At the bottom of such depressions, underlying grooved terrain and streamlined hills formed during catastrophic flood events are observed. Several mesa-like features are characterized by a rising sharp rim (fig. 16d). The mesas-like features lack any erosional marks such as grooves or terraces. Their walls are generally steep and layering is commonly recognizable. Layering is diverse in individual mesa-like feature or even on the different slopes of a mesa-like feature (fig. 16e).

Some morphological characteristics of the mesa-like features appear to be very similar to those of terrestrial kames, and thus they may have formed owing to similar geomorphic processes. Kames are steepsided, variably shaped mounds, composed mainly of sands and gravels. They form because of emplacement of sediments in ice-walled streams or lakes, in sub-glacial, englacial or supraglacial environments. These features were left as rising morphologies when surrounding ice melted (Benn and Evans, 1998). Commonly shared features characterizing both the mesa-like features of Ares Vallis and terrestrial kames are; steep walls, flat topmost part, irregularly-shaped morphology, layered structure, variations in layering of individual mesa-like features. The rising rim characterizing some mesa-like features of Ares Vallis is somewhat similar to those characterizing terrestrial ice-walled lake plains, which formed by sediments that accumulated near the margin of ice-walled lakes (Johnson and Menzies, 1996). The mesas-like features showing a reticulated pattern can be considered to be a gigantic version of terrestrial disintegration ridges, which formed by infilling of crevasses and other openings in disintegrating ice (Flint, 1971).

Our interpretation of the Martian features as ice-contact deposits mostly agrees with one of those proposed by Costard and Baker (2001), and implies that one or more ice masses filled Ares Vallis. Occurrence of such features requires that ice masses were stagnant at least from the time during which the probable kame features were emplaced until the ice wasted. The varying thickness of the ice-contact features implies i) differences in ice mass thickness along Ares Vallis, ii) variation in the amount of materials emplaced against ice masses, and finally iii) that sediments forming the probable kame features were deposited in different times throughout the wasting of the ice masses.

The materials forming the probable kame features seem to have originated from Ares Vallis walls, and appear to have been emplaced by fluvial-like processes (fig. 17). The bifurcating ridge of fig. 15 shows an olivine-rich composition and thermal inertia values higher than other surfaces occurring in the neighboring areas (Rogers et al., 2005). Thermal inertia values appear to be compatible with gravel and sand 
deposits, while the olivine-rich composition could be due to stream sorting processes. Indeed, olivine-rich layers occur on Ares Vallis walls (Rogers et al., 2005) and could represent source areas for sands and gravels forming the ridge.

Russell at al. (2001) describe a giant, supraglacial, ice-walled channel excavated into the snout of Skeiðarárjökull, Iceland, during the November 1996 jökulhlaup. The supraglacial channel was $500 \mathrm{~m}$ long, $100 \mathrm{~m}$ wide and $40 \mathrm{~m}$ deep. Mean flow velocities of the jökulhlaup ranged between 7 and $11 \mathrm{~m} \mathrm{~s}^{-1}$, which were capable of suspending sediments with grain size up to $20 \mathrm{~cm}$. Deposits occurring at the floor of the channel consist of an 8 meter thick succession of progradational and aggradational gravel macroforms. Russell et al. (2001) observe that, since the November 1996 jökulhlaup, ablation has lowered the surrounding glacier surface by approximately $30 \mathrm{~m}$, and the ice-walled channel has become a prominent flat-topped ridge. This feature could be one of the most interesting terrestrial analogs for the ice-walled stream deposits of Ares Vallis.

Alternative geomorphological processes of landscape evolution seem to be less likely for explaining the mesa-like features. Stream deposits not involving ice-masses can form inverted topography such as those observed in Eberswalde Crater on Mars (Malin and Edget, 2003). However, the patterns of the mesa-like features in Ares Vallis do not present expected fluvial forms such as tributary and distributary patterns. Lava flows could account for the olivine-rich composition of some ridges. Although ice-dammed lavas could form steep-sided lava flows, volcanic features are not observed in this area. The layering observed in Ares Vallis mesa-like features could have resulted from different insolation occurring at different facing slopes, and/or variable climates, leading to dissimilar erosive and/or sedimentary processes, which at places could have masked or enhanced sediment layering.

\subsubsection{Patterned terrains}

Terrains showing pitted or polygonal patterns appear in various reaches of the Ares Vallis Complex.

They occur at the highest stratigraphical level, and thus their emplacement may represent the latest of main geological events shaping the Ares Vallis Complex.

Pitted terrains consist of surfaces dotted by numerous hollows. Larger pits are $100 \mathrm{~m}$ wide, whereas the smallest ones distinguishable are 10-20 m wide. Pits have a quasi-circular shape, and sometime tend to aggregate each other. Typically, they exhibit dark floor, and sand dunes are recognizable on the largest ones. 
434 Patches of pitted terrains occupy floors of the Ares Vallis Complex and Eastern Valley Crater (fig. 18).

435 Furthermore, pits characterize mass wasting deposits occurring along Ares Vallis walls (fig. 19). In THEMIS

436 IR nighttime data, pitted terrains show higher emittance values than surrounding surfaces. Association of

437 pitted pattern and thermal properties of such terrains appears remarkable. This association, together with the

438 absence of pits on nearby terrains, leads us to hypothesize that pits formed because of soil properties, rather

439 than alternative causes (e.g. primary or secondary impact craters).

Terrains showing polygonal pattern generally embay the probable kame features occurring on the inner and deeper portions of Ares Vallis (fig. 15 and 16). There polygons appear to be hundreds of meters large and peripheral trenches are tens of meters wide. In THEMIS IR nighttime data, polygonal terrains show emittance values higher than Ares Vallis walls and lower than probable kame features.

Both the pitted and polygonal terrains may have originated because of periglacial processes. On

445 Earth, pitted patterns similar to those observed in the Ares Vallis Complex generally correlate with terrains subject to ground collapses due to thermokarstic processes. Possible terrestrial analogues are kettle-holes and thaw-lakes (Pacifici et al., 2005), which form when buried-ice or permafrost melts, forming pits on the surface. Polygonal terrains could have been formed also by desiccation processes. However, the occurrence of the probable kame features suggests that a periglacial origin is more likely. Melting of buried ice and upward movement of melt water could have originated ice cemented soils and duricrusts on Mars (Landis et al. 2004). Both ice-cemented soils and duricrusts could be responsible for the higher IR emittance values shown by patterned terrains with respect to surrounding surfaces.

The occurrence of geomorphological features related to periglacial processes, such as pitted and 454 polygonal terrains, agrees with the hypothesis that ice masses filled the Ares Vallis Complex in the past. 455 Moreover, periglacial features suggest that portions of the ice masses were buried after their emplacement. 456 Processes responsible for ice burying may have been mass wasting, emplacement of impact crater ejecta, or wind-blown materials, such as dust, sand, and volcanic ash. A sublimation till could have buried ice as well, if the original ice mass contained some amount of debris. Sublimation till of Beacon Valley in Dry Valleys,

459 Antarctica, shows a well-developed polygonal pattern (Marchant et al., 2002). Dry Valleys are known also as 460 one of the best Martian analogues on Earth. 


\section{Discussion}

\subsection{Catastrophic floods}

Some of the erosional and depositional morphologies occurring in the Ares Vallis Complex, such as

\section{7}

468

469

streamlined uplands, giant bars, pendant bars, and cataract-like features, suggest that Ares Vallis and its valley arms were shaped by catastrophic floods originating from chaos regions. This idea agrees with the previous hypothesis (Baker and Milton, 1974; Baker, 1982: Baker et al., 1992; Komatsu and Baker, 1997). Our geomorphological analysis of high-resolution images estimates that flood events were at least six. Reactivation of outflow channel flooding is indicated also at Tiu Vallis west of Ares Vallis (Rodriguez et al., 2005), thus it can be concluded that large circum-Chryse outflow channels were commonly formed by multiple floods. Occurrence of multiple floods is in agreement with numerical model of groundwater flow and surface discharge at the outflow channel sources (Harrison and Grimm, 2008). Topographic analyses of giant and pendant bars indicate that floods were at least $500 \mathrm{~m}$ deep in Narrow Ares Vallis, and at least 300 $\mathrm{m}$ deep at the Ares Vallis terminal reach. Geomorphological relationships indicate a progressive decreasing of fluid volume in the reservoirs during the discharges, which resulted in a progressive canalization of floods. This is partially in agreement with Nelson and Greeley (1999). Our hypothesis about the geomorphological evolution of Eastern Valley Crater (fig. 14) suggests that the amount of time elapsed between the two different floods in Eastern Valley must have been long enough to have permitted the emplacement of thermokarstic features $150 \mathrm{~m}$ deep and a few kilometres large. We do not know how much time was required for their formation. To make a roughly comparison, similar features 20 meters deep could require few hundreds of years to form on Earth (Brouchkov et al., 2004). Occurrence of layering could suggest two hypotheses. On the first one, each layer, a few tens of meters thick, formed during different floods; in the second hypothesis we suggest that layering formed because of variations in the flow regime during a single flood. Both the hypotheses appear to be consistent.

\subsection{Grooved terrains}

Grooved terrains characterize a large portion of the Ares Vallis Complex floors and erosional terraces, and occur also at other Martian outflow channels, such as in Kasei Valles. In earlier works on Martian outflow channels, main interpretations of grooved terrains were: i) features sculpted by high- 
velocity (catastrophic) flows of water (Baker and Milton, 1974) and ii) features similar to glacial scours and mega-flutes (Lucchitta, 1982; Lucchitta, 2001). In the former hypothesis grooves are considered to have been formed by powerful roller vortices, which developed parallel to the flow direction. In the latter hypothesis grooves are shaped by ice that in place moved through Martian channels. Ices flow similarly in Antarctic ice streams over deformable debris saturated with water under high pore pressure. Other hypotheses about groove origins including formation by roller vortices in fluids such as wind, debris flows and mudflows, were discussed in Baker et al. (1992) and Carr (1996). Origin of grooves could be inferred from geological relationships among grooves and nearby geomorphological features. In the Ares Vallis Complex, occurrence of cataract-like features, streamlined uplands, and pendant bars in association with grooved terrains (fig. 13) seems to support the cataclysmic flood origin.

Geomorphological characteristics of the observed grooves, and their relationship with respect to nearby features, such as meandering channels (fig. 6) and impact craters remnants (fig. 7), suggest that the grooves formed mainly on relatively "soft" highly erodible materials.

In areas where water flowed deeper and for longer durations (i.e., on the Ares Vallis floor) grooves appear wider and deeper than in the areas where water flowed shallower and for shorter times (i.e., in Western Valley). This appears in agreement with laboratory experiments and field observations. Laboratory experiments on water streams indicate that regular spacing of vortices in flow varies with velocity and depth of the flow (Allen, 1970). Field observations at the base of the Sigsbee Escarpment, in the northwestern Gulf of Mexico (Bean, 2003), show that strong currents formed mega-furrows on fine-grained sediments of seafloor. Higher current velocities and durations lead to form mega-furrow, which are wider, deeper and closer. Furthermore, the stronger sediments determine the maximum depth of erosion and require higher current velocity and duration to be eroded (Bean, 2003). Such seafloor mega-furrows exhibit some similarities with respect to Martian grooves. Therefore, it is possible that similar currents occurred at the bottom of Martian catastrophic floods. At the southern termination of Western Valley (fig. 4), grooves seem to converge and meet to form a deep and narrow canyon-like feature. This appears in agreement with some experimental flow simulations (Shepherd, 1972; Shepher and Schumm, 1974) showing as the longitudinal grooves form early and finally switch to a deep inner channel that progressively extends backward.

On the other hand, some variations in trough geometry and consequent fluid properties seem not to have significantly influenced processes sculpting grooves. Several flow properties could have varied along 
521

troughs, such as velocity, bedload quantity, granulometry density, fluid temperature, salt concentration, and amount of gases dissolved in the fluid. Martian grooves occur both in the proximity of the postulated fluid sources (fig. 8) and at the terminal reach of channels (fig. 9). This implies that grooves formed both in areas of convergence and divergence of floods, and in areas characterized by different topographic gradients (fig. 2). Furthermore, the large extension of grooves implies that same flow conditions were sustained for very long distances, such as several hundreds of kilometers. In Western Valley, despite the large variations in width of the trough (fig. 4), grooves do not show significant variations both in morphology and in dimensions along the entire $370 \mathrm{~km}$ long valley. A more detailed discussion on the groove formation during flooding requires precise determinations of water depth and flow velocity in various reaches of Ares Vallis, possibly by utilizing numeral modeling (e.g., Miyamoto et al., 2006; 2007).

\section{and glacial mega-lineations observed in sonar images of the sea floor in front of the Sea Ross Ice Shelf.} Intrigued by this striking similarity, we have compared high-resolution images of grooved terrains of Ares Vallis with sonar images of terrestrial glacial mega-flutes occurring on the floor of the Ontario Lake (fig. 5). Martian grooves consist of narrow and elongated troughs, while terrestrial glacial mega-flutes consist of elongated ridges. However, the overall shapes, the dimensions, and the spatial distributions of terrestrial and Martian features appear to be very similar. Mega-flutes of the Ontario Lake floor consist of compact stony diamict (till) (Lewis et al., 1997). Similar mega-flute observed on seafloors was interpreted as soft, structureless diamict (Dowdeswell et al., 2004), and subglacial till (Shipp and Anderson, 1997). Diamict and till are non-consolidated, poorly-sorted deposits: clasts vary from clay to boulders. Such kind of deposits could be similar to those forming some of Martian grooved terrains, which we interpret to consist of relatively "soft" highly erodible materials.

\subsection{Ice-covered catastrophic floods?}

Shaw $(1996,2002)$ proposed that terrestrial sub-glacial bedforms, such as those observed on the Ontario Lake floor, were shaped during the last ice age by enormous sub-glacial outburst floods. Sub-glacial floods are inferred to have formed meltwater sheets that flowed below ice masses producing mega-flutes, drumlins, tunnel valley and other sub-glacial bedforms. This theory is controversial (Benn and Evans, 1998), 
and thus Kargel (2004) suggests that this fact is sufficient to give a pause to any rapid judgment about Martian outflow channels. The catastrophic floods sculpting Ares Vallis could have somehow evolved in conditions similar to those of a sub-glacial outburst floods. In fact, Wallace and Sagan (1979) propose that, under the present climatic condition of Mars, a flowing channel of liquid water would be covered by ice, which evaporates slowly enough to allow the water below to flow for distances up to hundreds of kilometers, even with quite modest discharges. They calculated that thickness of such ice-covers ranging from tens to several hundreds of meters, and that the amount of ice lost by evaporation at the top surface is replaced by freezing at the bottom surface. This implies that the net loss is to the liquid water. Several factors could enhance or reduce the thickness of such ice-covers. These are: i) temperature of water in the reservoirs; ii) amount of possible salts and gases eventually dissolved in water; iii) composition and temperature of Martian atmosphere, and presence of atmospheric clouds or dusts; iv) possible different obliquity of Martian axis (Laskar and Robutel, 1993). Lucchitta (1982) proposed that in the cold Martian climate water coming from chaos regions was supercooled and then acquired rapidly large quantities of frazil ice, which locally may have developed ice caps. Some authors (Harrison and Grimm, 2008 and therein) suggest that in most cases groundwater discharge at chaotic terrain did not provide a direct source of channel flow but ponded locally and produced standing bodies of water; successively, outflow channel floods were triggered by jökulhlauptype events caused by failure of the lake margins. In this case, if ice masses formed on top of standing bodies of water, they could have been carried by catastrophic floods. Therefore, the formation of ice jams near obstacles and constrictions could have happened, successively followed by consolidation to form ice masses (Lucchitta, 1982). It is possible, then, that floods flowing in the Ares Vallis Complex could have provided enough ice to generate one or more ice masses hundreds of meters thick. Evidence for ice-rich deposits overlying catastrophic flood morphologies was observed in the Mangala Valles outflow channel (Levy et al., 2005). Observation of such deposit draped over grooved terrain suggests to these authors that ice would have formed on top of an outflow flood under cold-dry climatic condition.

If floods were ice-covered, they could evolve into a setting similar to a relatively thin water sheet flooding below an ice-cover, at least during their waning stage. In such condition, water flowing under the ice masses could have shaped grooved terrains, by processes similar to those proposed by Shaw (2002), and/or could have enhanced grooves already carved by roller vortices of catastrophic floods. Furthermore, in such sub-ice circumstances, it is possible that catastrophic floods maintained the same flow condition for 
very long distances, both in areas of converging and diverging flow (such as at the beginning and at the termination of Ares Vallis), and regardless of variations in width and depth of troughs. Possibly, small movements of ice cover may have occurred at the end of floods during the grounding of ice masses. This could have both enhanced or smoothed the previously shaped grooves.

\subsection{Glacial landscape}

Our geomorphological analyses point out that ice masses grounded on the Ares Vallis Complex floors subsequent to multiple catastrophic floods, forming one or more dead-ice bodies, and formed glacial landscapes. It appears very probable that tremendous erosive action of each catastrophic flood should have totally removed ice masses and possible glacial and periglacial features produced after previous flood events. At the present day, a glacial landscape formed following the last catastrophic flood event is still visible. They consist of ice-contact features and thermokarstic depressions. Arrangement of such morphologies allows us to perform a rough estimation of the areas covered by ice-masses. In the case of Wide Ares Vallis where probable kame features appear densely occurring, assuming that these features formed in a single ice mass, the final reach of Ares Vallis was infilled by a dead ice-mass as large as $3 \times 10^{4} \mathrm{~km}^{2}$. They varied in thickness between 100 to $500 \mathrm{~m}$. For the entire Ares Vallis Complex, the amount of ice infilling troughs should have been much higher than this value.

Evidence for a glacial landscape is absent in Western Valley. This may be due to the fact that Western Valley seems to have been carved by only one catastrophic flood. And the glacial landscape (possibly) emplaced at the end of such flood may have totally sublimate/melted without subsequent reworking. It is also possible that Western Valley was flooded for a brief time, or during warmer-wetter climatic conditions (see below), and then the resulting ice-cover was thinner than in other valleys. Finally, it is possible that fluid emanating from Hydaspis Chaos could have had a different temperature and/or composition in salts with respect to those of Iani and Aram Chaos, and then emplaced a thinner ice mass.

In the current Martian environment, ice once grounded could remain in place for a long time before totally sublimating or melting. Both morphological analyses (Levy et al., 2005) and models (Clifford and Parker, 2001) suggest this situation. In such an environment, ice masses could have preserved underlying grooved terrains from erosion, and could have favored consolidation of loose materials at their base. The pristine appearance of the grooved terrains and probable kame features in the Ares Vallis Complex may 
suggest that ice masses disappeared mainly by sublimation processes, not by melting. Regarding the efficiency of sublimation processes on Mars, Clifford and Parker (2001) suggest that at latitudes lower than $40^{\circ}$, which is the case of Ares Vallis, sublimation rates from a bare ice surface could readily exceed $0.1 \mathrm{~m} \mathrm{yr}$

${ }^{-1}$. However, the presence of a debris mantle only $10-20 \mathrm{~cm}$ thick could reduce the sublimation rates by more than one order of magnitude. Considering both these end-members, the time required to sublimate a $500 \mathrm{~m}$ thick stagnant ice mass varies from 5000 to 50000 years, respectively in cases of bare and mantled ice. Mantling of ice could have been caused by emplacement of wind-blown sand, dust, volcanic ash, slope failure materials and impact crater ejecta. If the dead-ice masses contained some amount of debris, which is possible because of its origin, a sublimation till could have developed as well, lowering ice sublimation rate. Patterned terrains of the Ares Vallis Complex, and their thermal properties, suggest that periglacial processes occurred, and support the idea that ice was mantled or mixed with debris.

Periods of high or low obliquity of Mars, if occurred, could have increased or decreased ice sublimation rate. Observation of thermokarstic features, probable kame features, and relatively small-scale meandering channels, which seem to have been formed subsequent to multiple catastrophic flood events, suggests that relatively brief periods of warmer-wetter climatic conditions took place (see below), which could have favored melting rather than sublimation processes.

\subsection{Climatic changes}

Some morphological features of the Ares Vallis Complex are interpreted as formed by flowing or standing bodies of water in equilibrium with the Martian atmosphere. Such features are i) narrow, meandering channels, ii) thermokarstic features, and iii) probable kame features. Development of such features requires that periods of warmer-wetter climatic conditions took place. Thermokarstic features (fig. 14) and hanging channels (fig. 13 and fig. 15) formed both on erosional terraces and icy deposits shaped by floods, and were modified by subsequent floods deepening troughs. This suggests that they developed between different catastrophic flood events. We hypothesize that such warmer-wetter climatic conditions were triggered by catastrophic flood events themselves. In fact, water vapor and carbon dioxide/methane gases liberated into the Martian atmosphere by degassing during outflow events could have induced a shortterm greenhouse effect (Baker et al., 1991; Gulick et al., 1997; Baker, 2001). Water vapor released by wasting of stagnant ice-masses could have also sustained the greenhouse effect. 

may suggest that, in spite of the earlier warmer-wetter conditions, the main wasting of ice masses was driven by sublimation processes. This implies that the warmer-wetter climatic conditions occurred for relatively brief spans of time. Subsequently, climatic conditions became similar to those of the present day. Our observations agree with Baker (2001), which proposed that a short-duration, transient, warmer-wetter period followed the activation of catastrophic floods, and that afterward the Martian climate comes back to climatic conditions similar to those of the present day.

\section{6 - Conclusion}

The Ares Vallis Complex is one of the longest and ancient systems of outflow channels on Mars.

647 Some of its morphological features (i.e. grooved erosional terraces, streamlined uplands, pendant bars, and cataract-like features) appear to have originated by multiple, time-scattered, catastrophic floods. Other morphological features (i.e. probable kame features, thermokarstic depressions, and patterned terrains) indicate that Ares Vallis hosted dead-ice masses in the past. Geological relationships between the catastrophic flood features and the ice-related features depict a possible geological evolution of Ares Vallis,

652 involving a cyclic series of geomorphic processes (fig. 20) consisting of i) multiple, ice-covered catastrophic floods; ii) grounding of ice-masses formed on top of floods; iii) emplacement of ice-contact deposits, and finally iv) ice wasting.

i) The Ares Vallis Complex originated by enormous floods discharged from chaotic terrains. The floods were responsible for sculpting grooved terrains, erosional terraces, streamlined uplands, and giant cataract-like features. The grooved terrains formed both at the proximal and at the distal reaches of the Ares Vallis Complex, and were originated by powerful vortices at the base of the enormous floods. Grooves formed prevalently on relatively erodible "soft" terrains, and their dimensions seem to vary depending on thickness and duration of the floods. Depositional features emplaced by floods consist of giant bars and 662 pendant bars.

ii) Ice-covers formed on top of floods because of low values of temperature and pressure of Martian atmosphere. The amount of ice lost by evaporation at the top surface reformed by freezing at the bottom surface, allowing the ice-cover to thicken up to several tens to few hundreds of meters. As the floods 
decreased their discharges, this setting evolved into a thick ice mass topping a relatively thin layer of flowing water. In such conditions, subglacial floods contributed to or enhanced sculpting of grooves.

iii) At the end of the floods, ice-covers grounded on the valley floor, forming thick, dead-ice masses.

The ice masses could have taken a long time to totally waste (about a few thousand to a few tens of thousand of years, respectively in case of bare and debris mantled ice). Warmer-wetter climatic conditions prevailed during the first stage of wasting of the ice, and streams of water etched ice masses forming ice-walled channels and lakes. Origin of such water streams seems to be related to melting of permafrost and/or ice. The warmer-wetter climatic conditions were triggered probably by the greenhouse effect caused by water vapor and carbon dioxide/methane gases released during the catastrophic flood processes. If catastrophic flood events occurred during the warmer-wetter climatic conditions, it is plausible that they were ice free.

iv) Finally, ice masses totally wasted. Ice wasting produced a landscape inversion and materials deposited at the floor of ice-walled channels and lakes turn into mesa-like features, similarly to terrestrial kame deposits. Pristine appearance of sub-glacial and supra-glacial features (i.e. grooved terrains and probable kame features, respectively) suggests that colder-dryer conditions prevailed during the second stage of dead-ice mass wasting. This leads us to think that the greenhouse effect persisted no longer than the time required to totally waste the ice masses infilling Ares Vallis.

Quantitative geomorphological analysis, realized by using high-resolution images and HRSC stereoderived DTMs, allowed us to estimate some parameters about catastrophic floods and glacial masses. At least six catastrophic floods originated in Iani Chaos and sculpted Ares Vallis, at least two (probably more) originated in Aram Chaos. Water emanating from Hydaspis Chaos fed the Ares Vallis Complex during one single catastrophic flood event. On the narrow reach of Ares Vallis, floods had a minimum depth of about $500 \mathrm{~m}$, estimated on the base of thicknesses of giant bars. In Wide Ares Vallis, instead, thicknesses of pendant bars suggest a minimum depth of about $300 \mathrm{~m}$. Arrangement of ice-related features and their thicknesses allow estimating the minimum aerial extent and thickness of the ice-mass(es) in which they formed. Ice mass(es) was one to five hundreds of meters thick and tens of thousand of square kilometers in area.

Throughout the wasting period of dead-ice mass(es), ice were locally buried by mass wasting processes, wind-blown materials, debris flows, and possibly by sublimation till. Periglacial processes acting on the buried ice formed patterned terrains and ice-cemented soils. 
Acknowledgement:

703 We would like to thank Professor V.R. Baker for its helpful suggestions and comments. We thank the HRSC Experiment Teams at DLR Berlin and Freie Universitaet Berlin as well as the Mars Express Project Teams at ESTEC and ESOC for their successful planning and acquisition of data as well as for making the processed data available to the HRSC Team. We acknowledge the effort of the HRSC Co-Investigator Team members and their associates who have contributed to this investigation in the preparatory phase and in scientific discussions within the Team. We would like to thank for the reviews by Keith Harrison and Cathy Quantin, which greatly improved this work with suggestions and observations. This research was supported by Agenzia Spaziale Italiana.

\section{References}

713 Allen, J.R.L., 1970. Physical Processes of sedimentation. American Elsevier, New York.

Aguirre-Puente, J., Costard, F., Posado-Cano, R., 1994. Contribution to the study of thermal erosion on

Baker, V.R., 1982. The Channels of Mars. Univ. of Texas Press, Austin.

Baker, V.R., 2001. Water and the Martian landscape. Nature, 412, 228-236.

Baker, V.R., Milton, D.J., 1974. Erosion by Catastrophic Floods on Mars and Earth. Icarus, 23, 27-41. 
Baker, V.R., Strom, R.G., Gulick, V.C., Kargel, J.S., Komatsu, G., Kale, V.S., 1991. Ancient oceans, ice sheet and the hydrological cycle on Mars. Nature, 352, 589-594.

Baker, V.R., Carr, M.H., Gulick, V.C., Williams, C.R., Marley, M.S., 1992. Channels and valley networks. In: Kieffer, H.H., Jakosky, B.M., Synder, C.W., Matthews, M.S. (Eds.), Mars. University of Arizona Press, Tucson, pp. 483-522.

Bean, D.A., 2003. Characteristics of mega-furrows on the continental rise seaward of the Sigsbee Escarpment, Gulf of Mexico. In: Depositional processes and characteristics of siltstones, mudstones and shales. SEPM ( Society for Sedimentary Geology).

Benn, D.I., Evans, D.J.A., 1998. Glaciers \& glaciation. Arnold, London.

Brouchkov, A., Fukuda, M., Fedorov, A., Konstantinov, P., Iwahana, G., 2004. Thermokarst as a Short-term Permafrost Disturbance, Central Yacutia. Permafrost and Periglac. Process. 15, 81-87.

Burr, D.M., Carling P.A., Beyer, R.A., Lancaster, N., 2004. Flood-formed dunes in Athabasca Valles, Mars: morphology, modeling, and implications. Icarus, 171, 68-83.

Carling, P.A., Kirkbride, A.D., Parnachov, S., Borodavko, P.S., Berger, G.W., 2002. Late quaternary catastrophic flooding in the Altai Mountains of south-central Siberia: a synoptic overview and an introduction to flood deposit sedimentology. Spec. Publs. Int. Ass. Sediment. 32, 17-35.

Carr, M.H., 1996. Water on Mars. Oxford University Press, Inc. New York.

Carr, M.H., Shaber, G.G., 1977. Martian Permafrost Features. J. Geophys. Res. 82 (28), 4039-4054

Clifford, S.M., Parker, T.J., 2001. The evolution of the Martian hydrosphere: implication for the fate of a primordial ocean and the current state of the northern plains. Icarus, 154, 40-79. 
754 Costard, F., 1989. Fluvio-thermal erosion on Mars: a siberian analogy. Lunar and Planet. Sci. XX, 189-190. 755

756 Costard, F., Dollfus, A., 1986. Ice lenses on Mars. Lunar and Planet. Sci. XVII

Costard, F.M., Kargel, J.S., 1995. Outwash Plains and Thermokarst on Mars. Icarus, 114, 93-112

Costard, F., Baker, V.R. 2001. Thermokarst landform and processes in Ares Vallis, Mars. Geomorphology, $37,289-301$.

Czudek, T., Demek, J., 1970. Thermokarst in Siberia and its influence on the development of lowland relief. Quaternary Res., 1, 103-120.

Dowdeswell, J.A., Ó Cofaigh, C., Pudsey, C.J., 2004. Thickness and extent of the subglacial till layer beneath an Antarctic paleo-ice stream. Geology, 32 (1), 13-16.

Flint, R.F., 1971. Glacial and quaternary geology. Wiley, New York.

Glicken, H., Schultz P.H., 1980. Martian Channel Erosion: The lahar analogy. Lunar and Planet. Sci. XI, 330-332.

Golombek, M.P., Cook, R.A., Economou, T., Folkner, W.M., Haldemann, A.F.C. , Kallemeyn, P.H., Knudsen, J.M., Manning, R.M., Moore, H.J., Parker, T.J., Rieder, R., Schofield, J.T., Smith, P.H., Vaughan, R.M., 1997. Overview of the Mars Pathfinder Mission and Assessment of Landing Site Predictions. Science, 278, (5344), 1743 - 1748. 
782

783

784

785

786

787

788

789

790

791

Harris, S.A., 2002. Causes and Consequences of Rapid Termokarst Development in Permafrost or Glacial Terrain. Permafrost and Periglac. Process., 13, 237-242.

Harrison, K. P., Grimm, R.E., 2008. Multiple flooding events in Martian outflow channels. J. Geophys. Res., 113, E02002, doi:10.1029/2007JE002951.

Hartmann, W.K., 2005. Martian cratering 8: Isocrhon refinement and the chronology of Mars. Icarus, 174, 294-320.

Johnson, W.H., Menzies, J., 1996. Pleistocene Supraglacial and ice-marginal deposits and landforms. In: Menzies, J. (Ed), Past Glacial Environments: Sediments, Forms and Techniques - (Glacial Environments Series; 2), Butterworth-Heinemann, Oxford, pp. 137-160.

Johnson, M.D., Mickelson, D.M., Clayton, L., Attig, J.W., 1995. Composition and genesis of glacial hummocks, western Wisconsin, USA. Boreas, 24, 97-116.

Kargel, S.J., 2004. Mars - A Warmer, Wetter Planet. Springer Praxis Books / Space Exploration.

Komatsu, G., Baker, V.R., 1997. Paleohydrology and flood geomorphology of Ares Vallis. J. Geophys. Res., 102 (E2), 4151-4160.

Landis, G.A., Blaney, D., Cabrol, N., Clark, B.C., Farmer, J., Grotzinger, J., Greeley, R., McLennan, S.M., Richter, L., Yen, A., and the MER Athena Science Team, 2004. Transient liquid water as a mechanism for induration of soil crust on Mars. Lunar and Planet. Sci. XXXV.

Laskar, J., Robutel, P., 1993. The chaotic obliquity of the planets. Nature, 361, 608-612.

Leverington, D.W., 2004. Volcanic rilles, streamlined islands, and the origin of outflow channels on Mars. J. Geophys. Res., 109 (E10), 1-14 
812 Levy J.S., Head, J.W., Marchant, D.R., Kreslavsky, M. 2005. Evidence for remnats of late Hesperian ice-rich deposits in the Mangala Valles outflow channel. Lunar and Planet. Sci. XXXVI.

814

815 Lewis, C.F.M., Mayer, L.A., Cameron, G.D.M., Todd, B.J., 1997. Drumlins in Lake Ontario. In Davies, T. (Eds), Glaciated continental margins: an atlas of acoustic images. Chapman \& Hall, London, pp. 4849. 403-406.

Malin, M.C., Edgett, K.S., 2001. Mars Global Surveyor Mars Orbiter Camera: Interplanetary cruise through primary mission. J. Geophys. Res., 106 (E10), 23,429-23,570.

Malin, M.C., Edgett, K.S., 2003. Evidences of persistent flow and aqueous sedimentation on early Mars.

Marchant, D.R., Lewis, A.R., Phillips, W.M., Moore, E.J., Souchez, R.A., Denton, G.H., Sugden, D.E., Potter, N. Jr., Landis, G.P., 2002. Formation of patterned ground and sublimation till over Miocene glacier ice in Beacon Valley, southern Victoria Land, Antarctica. GSA Bullettin, 114 (6), 718. 
841 842 843

844 845 846 847 848

Marchenko A.G., Basilevsky A.T., Hoffmann, H., Hauber, E., Cook, A.C., Neukum, G., 1998. Geology of the common mouth of the Ares and Tiu Valles, Mars. Solar System Res., 32 (6), 425-452.

Miyamoto, H., Itoh, K., Komatsu, G., Baker, V.R., Dohm, J.M., Tosaka, H., Sasaki, S., 2006. Numerical simulations of large-scale cataclysmic floodwater: A simple depth-averaged model and an illustrative application. Geomorphology 76, 179-192.

Miyamoto, H., Komatsu, G., Baker, V.R., Dohm, J.M., Itoh, K., Tosaka, H., 2007. Cataclysmic Scabland flooding: Insights from a simple depth-averaged numerical model. Environmental Modelling and Software 22, 1400-1408, doi:10.1016/j.envsoft.2006.07.006.

Nelson, D.M., Greeley, R., 1999. Geology of Xanthe Terra outflow channels and the Mars Pathfinder landing site. J. Geophys. Res., 104 (E4), 8653-8669.

Pacifici, A., 2008. Geomorphological map of Ares Vallis, Mars - ASI Planetary Map Series - Map n 1. Boll.Soc.Geol.It. (Ital.J.Geosci.), 127 (1), 75-92.

Pacifici, A., Ori, G.G., Neukum, G., and the HRSC Co-Investigator team, 2005. High-resolution morphological analysis of the central part of Ares Vallis using HRSC, MOC and THEMIS data. First Mars Express Science Conference.

Robinson, C.A., Neukum, G., Hoffmann, H., Marchenko, A., Basilevsky, A.T., Ori, G.G., 1996. A suggested geological development for Ares Vallis, Mars. Lunar and Planet. Sci. XXVII.

Rodriguez, J.A.P., Sasaki, S., Kuzmin, R.O., Dohm, J.M., Tanaka, K.L., Miyamoto, H., Kurita, K., Komatsu, G., Fairén, A.G., Ferris, J.C., 2005. Outflow channel sources, reactivation, and chaos formation, Xanthe Terra, Mars. Icarus, 175, 36-57. 
869 Rogers, A.D., Christensen, P.R., Bandfield, J.L., 2005. Compositional heterogeneity of the ancient Martian 870 crust: Analysis of Ares Vallis bedrock with THEMIS and TES data. J. Geophys. Res., 110, E05010,

872

873 Russel, A.J., Knudsen, Ó., Fay, H., Marren, P.M., Heinz, J., Tronicke, J., 2001. Morphology and sedimentology of a giant supraglacial, ice-walled, jökulhlaup channel, Skeiðarárjökull, Iceland: implications for esker genesis. Global and Planetary Change, 28, 193-216.

Shaw, J., 1996. A meltwater model for Laurentide subglacial landscape. In : McCann, S.B., Ford, D.C., (Eds.), Geomorphology sans Frontière. Wiley, Chichester, pp. 182-226.

Shaw, J., 2002. The meltwater hypothesis for subglacial bedforms. Quaternary International, 90, 5-22.

Shepherd, R.G., 1972. Incised River Meanders: Evolution in Simulated Bedrock. Science, 178 (4059), 409-

Shipp, S., Anderson, J.B., 1997. Drumlin Field on the Ross Sea Continental Shelf, Antartica. In Davies, T. (Eds), Glaciated continental margins: an atlas of acoustic images. Chapman \& Hall, London, pp. 52-

Sudgen, D.E., Marchant, D.R., Potter, N.Jr., Souchez, R.A., Denton, G.H., Swisher, C.C.III., Tison, J., 1995. Preservation of Miocene glacier ice in East Antarctica. Nature, (376), 412-414.

\footnotetext{
Tanaka, K.L., 1997. Sedimentary history and mass flow structures of Chryse and Acidalia Planitiae, Mars. J.
} Geophys. Res. 102 (E2), 4131-4149 
898 Tanaka, K.L., 1999. Debris-flow origin for the Simud/Tiu deposit on Mars. J. Geophys. Res., 104 (E4), 8637 $-8651$.

900

901 Tanaka, K.L., Skinner, J.A., Hare, T.M., 2005. Geologic Map of the Northern Plains of Mars. U.S. 902 Geological Survey Scientific Investigations Map 2888, [available on World Wide Web at 903 http://pubs.usgs.gov/sim/2005/2888/].

904

905 Werner, S., 2005. Major Aspects of the Chronostratigraphy and Geologic Evolutionary History of Mars. Ph.D. thesis, Freie Universität, Berlin.

907

908 Wallace, D., Sagan, C., 1979. Evaporation of ice in planetary atmospheres: Ice-covered rivers on Mars. Icarus, 39, 385-400.

910

Figure captions

918 Fig. 1. Location map of Ares Vallis Complex area based on the MOLA grid data. Frames refer to other 919 figures.

921 Fig. 2. Longitudinal profile of Ares Vallis obtained from MOLA grid data. Notice the lowest portion of the

922 valley resides in the narrow reach. Arrows indicate merging points of main valley arms debouching on Ares 923 Vallis. 
925 Fig. 3. Upstream reach of Ares Vallis. Arrangement of erosional terraces and streamlined uplands shows

926 that at least six main catastrophic flood events sculpted Ares Vallis. The terrace formed during the first

927 catastrophic flood event shows relative shallow anastomosing channels. Erosional terraces marking

928 subsequent floods illustrate the progressive deepening and channelization of Ares Vallis. Frames refer to

929 other figures. Mosaic of HRSC h0934_0000, h0923_0000, and h0912_0000 images; topographic profile

930 obtained from HRSC DTM mosaic.

932 Fig. 4. Western Valley topography from MOLA grid data. Arrows indicate flow directions as suggested from 933 morphological features. Transversal topographic profile (AB) illustrates that Western Valley appears to be 934 characterized by an elevated width-to-depth ratio (vertical exaggeration of profile is four times). Double935 arrowed bar indicates lateral extension of grooved terrain. Frames refer to other figures.

937 Fig. 5. Grooves characterizing floors and erosional terraces of the Ares Vallis Complex consist of equally spacing furrows or trenches between narrow ridges. The most morphologically similar features observed on

939 Earth are the glacial mega-flutes. a) Martian grooves; image MOC R1101630. b) Close up. c) Martian

940 grooves; image THEMIS V12795005. d) Mega-flutes on sonar image of the Ontario Lake floor; reprinted

941 from Quaternary International, Vol. 90, J. Shaw, The meltwater hypothesis for subglacial bedforms, Pages

942 No 5-22, Copyright (2002), with permission from Elsevier. e) Mega-flutes on sonar image of the Ontario

943 Lake floor; modified from Glaciated continental margins: an atlas of acoustic images. Chapman \& Hall,

944 London, 1997.

946 Fig. 6. Three-dimensional view of a portion of Western Valley and Aram Chaos rim; HRSC h1000_0000

947 image draped on HRSC DTM. See fig. 4 for location. a) The narrow outlet channel emanating from a $50 \mathrm{~km}$

948 wide impact crater located on the extended rim of Aram Chaos meets the central portion of Western Valley.

949 Comparison between the channel 100-250 m deep and the grooves allows hypothesizing that the grooves are

950 no more than some meters or a few tens of meters deep. b) At its downstream portion, the meandering

951 channel etches the grooved floor of Western Valley and appears truncated by a shallow, small, chaotic

952 region. c) The meandering channel does not show variations in proximity of the transition from the grooved

953 to the non-grooved terrain, suggesting that geological properties of grooved and not-grooved terrains are 
954

955

956

957

958

959

960

961

962

963

964

965

966

967

968 d). Sketch illustrating a possible origin of streamlined uplands. abandoned meanders. image.

similar. d) HRSC h1000_0000 and MOC E0900989 images mosaic showing a close-up of channel and its

Fig. 7. Impact crater remnants (black arrows) on the erosional terraces of Ares Vallis. Absence of grooves on the topmost part of the remnants suggests that grooves form mainly on relatively "soft" erodible materials. Notice the annular furrows embaying crater remnants. HRSC h1066_0000 image. See figure 16 for a context

Fig. 8. Western Valley proximal reach in the vicinity of Hydaspis Chaos; see fig. 4 for location. This area consists of a fan-shaped system of broad, shallow, and grooved channels, which converge and meet together in the downstream. Higher parts of streamlined uplands appear to be flat and non-grooved. Lower parts appear to be grooved. Arrangement of grooves and streamlined uplands, and crosscutting relationships among channels, indicate an overall converging pattern of floods. HRSC h1022_0000 image.

Fig. 9. a) Three-dimensional view of terminal reach of Ares Vallis; HRSC h1619_0000 image draped on MOLA grid data. This portion of the valley is characterized by streamlined uplands ( $\mathrm{Su}$ ) and pendant bar $(\mathrm{Pb} 1, \mathrm{~Pb} 2$, and $\mathrm{Pb} 3)$. $(\mathrm{P})$ indicates the Mars Pathfinder landing site. b) Probable kame features (M) clearly overlie a streamlined upland (Su); HRSC h01980_0000 image draped on HRSC DTM.

Fig. 10. Streamlined uplands at the terminal reach of Ares Vallis. a) In areas of diverging floods, streamlined uplands commonly show an impact crater (C) on their upstream portion. Grooves characterize valley floor surrounding streamlined uplands. Next to the gently raising northeastern wall of Wide Ares Vallis, grooves degrade into transversal, relatively small ridges. Wing-shaped deposits overlie downstream portion of uplands and nearby grooved terrains. Wrinkle ridges (Wr) clearly postdate other features. Mosaic of HRSC h0155_0001 and THEMIS V12795005, V04782003, V10349017, and V14330014 images. b) Threedimensional view of streamlined uplands; mosaic of HRSC and THEMIS VIS images draped on HRSC DTM. c) Transversal and longitudinal topographic profile of streamlined uplands derived from HRSC DTM. 
983 Fig. 11. Possible giant bar in an alcove sculpted along the right wall of the narrowest portion of Ares Vallis.

984 Nadir a) and 3D view b) of a portion of HRSC h1022_0000 image. c) Close-up: possible boundary between

985 the giant bar and the grooved terrain is highlighted (MOC Na R0401710). d) Topographic profiles obtained

986

987

988

989

990

991

992

993

994

995

996

997

998

999

1000

1001

1002

1003

1004

1005

1006

1007

1008

1009

1010

1011

Fig. 12. Pendant bars at the terminal reach of Ares Vallis; see fig. 9 for location. a) Parabolic erosional scour (S) forms upstream of the bedrock projection because of acceleration of flow in nearness of a bedrock projection; HRSC h2002_0001 image. b) Three-dimensional view of Pb1; HRSC image draper on HRSC DTM. c) Sediments emplaced on the inner and deeper portion of troughs during the final stage of catastrophic floods overlap parabolic scours and lower portions of pendant bars; HRSC h1154_0001 image. d) Three-dimensional view of Pb2; HRSC image draped on HRSC DTM. e) Close-up of a pendant bar: bedrock projection $(\mathrm{Bp})$ and pendant bar $(\mathrm{Pb} 3)$ are easily distinguishable. Laterally to the pendant bar, small troughs (solid lines) formed because of enhancement of flow energy: arrows indicate flow direction; wrinkle ridge (Wr) postdates the last depositional event. Portion of MOC E2200200 image. f) Interpretative sketch illustrating development of a pendant bar.

Fig. 13. a) HRSC mosaic of a cataract-like feature; see fig. 4 for location. Cataract-like feature (C) forms next to a scarp (F) and successively extends upstream for about 35 kilometers by backward erosion of the headwall. Grooved terrain $(\mathrm{G})$, pendant bar $(\mathrm{Pb})$ and streamlined upland $(\mathrm{Su})$ occur upstream of the cataractlike feature. Downstream of the cataract-like feature, all these erosional morphologies disappear; only a few small streamlined remnants (R) occur. Notice sapping channels (S) emanating from a geological contact between two different layers forming Noachian plateau, and hanging on Ares Vallis. HRSC h1022_0000 and h1011_0000 image mosaic. b) Three-dimensional view of the area; HRSC mosaic draped on HRSC DTMs mosaic; vertical exaggeration $=5$.

Fig. 14. a) Several coalescing, flat-floored, depressions (Td), possibly thermokarstic in origin, characterize materials infilling Eastern Valley Crater. Smaller and shallower depressions (sTd) appear not connected to others. Eastern Valley incises and postdates the coalescing depressions. Mosaic of HRSC h0912_0000 and h0901_0000 images; see fig. 1 for location. b) Sketch illustrating a possible geomorphological evolution of 
1012 Eastern Valley Crater. Flooding and non-flooding periods alternate. During the flooding period ice-rich

1013 deposits were emplaced, while during the non-flooding period ice wasted. The non-flooding period must

1014 have been long enough to allow the shaping of thermokarstic depressions.

1015

1016 Fig. 15. a) A bifurcating ridge (Br) outcrops on the valley floor, and possibly represents an ice-walled stream

1017 deposit evolved after ice wasting. Black arrows indicate flow directions of the inferred ice-walled stream. A

1018 fault $(\mathrm{F})$ truncates the upstream portion of Br. Polygonal terrains (Pt) outcrop at the bottom of closed

1019 depressions (which often appear as exhumed impact crater) and postdate Br. Meandering channel (Mc)

1020 emanating from the flat-floored impact crater (C) and thermokarstic depressions (Td) etches erosional

1021 terraces (t1-t4); Ares Vallis truncates and postdates the meandering channel. HRSC h0945_0000 e

1022 h0934_0000 images mosaic; see fig. 1 for location. b) Three-dimensional close-up. Br bifurcates next to a

1023 streamlined hill (Sh): the up-convex northern branch of Br suggests that at least this portion of the ice-walled

1024 stream flowed in a sub-ice tunnel. Erosional terraces shaped during later catastrophic flood events (t2-t4) are

1025 poorly developed with respect to the first one ( $\mathrm{t} 1)$, and then are not easily distinguishable. Notice the

1026 meandering channel Mc termination hanging on Ares Vallis. HRSC mosaic draped on HRSC DTMs mosaic.

1027 Vertical exaggeration $=3$.

1028

1029 Fig. 16. Close-ups and context image of probable kame features and underlying grooved terrains

1030 characterizing Wide Ares Vallis. a) Topmost part of the largest probable kame features appears to be etched

1031 by thermokarstic depressions (Td) of which floors streamlined features and patches of underlying grooved

1032 terrains (dashed lines) commonly outcrop. b) Polygonal terrains (Pt) surround probable kame features

1033 occurring at the inner and deeper portions of the valley. Arrows highlight the layered structures of probable

1034 kame features. c) Probable kame features showing reticulated shape (dashed lines). d) Rising rim (Rr) on top

1035 of a probable kame feature. Portion of MOC R1800149. e) Individual probable kame features show various

1036 layering: a dark layer clearly occurs on the wall of the probable kame $\mathrm{K} 1$, while is not observable on the

1037 neighboring probable kame K2. Portion of MOC M2001237. f) Context image for image a, b, c, and figure 7.

1038 Image HRSC h1066_0000. 
1040 Fig. 17. a) Interpretative three-dimensional sketch illustrating relationships among erosional terraces,

1041 probable kame features, and the Ares Vallis floor. Sinuous channels partially etch the outermost grooved

1042 terraces (t1) and run toward the inner portion of Ares Vallis. Toward downstream, channels turn into

1043 elongated, slightly sinuous ridges and mesas $(\mathrm{K})$, which overlie the innermost terraces (t1-2) and extend on

1044 valley floor (Vf). THEMIS V12770013, V10012003, and V13394008 mosaic draped on HRSC h0155_0001

1045 stereo-derived DTM; vertical exaggeration = 3. b) Sketch illustrating a possible geological evolution of

1046 probable kame features. 1) Subsequent to catastrophic flood processes Ares Vallis was infilled by ice; 2)

1047 stream of water carved sinuous channels on both areas uncovered by ice and on the ice mass, emplacing

1048 fluvio-glacial deposits; 3) Ice wasting caused the landscape inversion, originating sinuous ridges and mesas

1049 consisting of fluvio-glacial deposits. The thickness and spatial distribution of such kame features imply that

1050 an ice mass up to hundreds of meters thick infilled Ares Vallis at the time in which fluvio-glacial deposits

1051 were emplaced.

1052

1053 Fig. 18. Pitted terrains consist of areas dotted by numerous hollows tens of meters wide. Such terrains show

1054 higher radiance values in THEMIS IR nighttime image with respect to nearby areas (see the color-coded

1055 bar). Association of such morphological and thermal properties suggests that ground-ice occurred in the past

1056 (and possibly at the present day) and that pits originated by ground-ice wasting. a) In the terminal reach of

1057 Aram Chaos Channel, pitted terrains occur exclusively at the valley floor (Vf), and they lack on valley walls

1058 and terraces (T); data fusion of MOC E0301279 and THEMIS IR Night mosaic; see fig. 3 for location. b) On

1059 the floor of Eastern Valley Crater, pitted terrains occur on top of crater floor deposits (Cf), and as patches at

1060 the bottom of thermokarstic depressions (Td), where they are less distinguishable. Walls of thermokarstic

1061 depressions show layering (at least four) tens of meters thick; arrows indicate boundaries (b1, b2, b3) among

1062 different layers. Data fusion of MOC E1700126 and THEMIS IR Night mosaic; see fig. 14 for location.

1064 Fig. 19. Three-dimensional view of a portion of the narrow reach of Ares Vallis. Here valley terrace

1065 collapsed as a slump that overlaps and postdates grooved terrains (G) and valley floor. The slump deposit

1066 shows a pitted patterned surface $(\mathrm{P})$, suggesting burying of ice and the following activity of periglacial

1067 processes. Notice the thermokarstic depressions (Td) etched on the terrace. HRSC h0934_0000 and

1068 h0923_0000 images mosaic draped on HRSC DTMs mosaic; vertical exaggeration $=3$. 
1070 Fig. 20. Sketch (not to scale) illustrating cyclic events responsible for sculpting of Ares Vallis. 1) An 1071 enormous flood discharged from chaotic terrains and sculpted Ares Vallis. 2) It shaped grooved terrains and 1072 other erosional morphologies at its base, while ice cover formed on its top because of Martian climatic 1073 condition. Grooved terrains form by powerful vortices acting at the base of the flood. 3) During the waning 1074 stage of flood, a relatively thin sheet of water flowed at the bottom of a thick ice-cover. In this condition, 1075 sculpting of grooves was enhanced. 4) At the end of the flood the ice-cover grounded on the valley floor 1076 forming a thick mass of dead-ice. Climate started to be warmer and wetter because of greenhouse effect of 1077 water vapor and carbon dioxide/methane gas released during catastrophic floods. 5) Such climatic condition 1078 favored ice melting and allowed presence of liquid water on the surface, which etched the ice mass forming 1079 ice-walled channels and lakes, besides thermokarstic depressions. 6) Greenhouse effect faded and liquid 1080 water disappeared from the surface. Climate progressively came back to cold-dry conditions. 7) In such 1081 climatic condition ice continued to waste by the prevailing sublimation process. Materials deposited on the 1082 floor of ice-walled channels and lakes became kame features, which overlie both grooved terrains and 1083 streamlined features. The pristine appearance of grooved terrains and kame features suggests that colder1084 dryer conditions prevailed during most part of ice-mass wasting. 8) Ice mass totally wasted and it caused the 1085 ice-contact features to be overlying erosional features. If some catastrophic floods occurred during wet-warm 1086 climatic conditions, they probably were ice-free. In this case floods simply deepened Ares Vallis, removing 1087 ice masses and ice-related features occurring on the valley floor. 


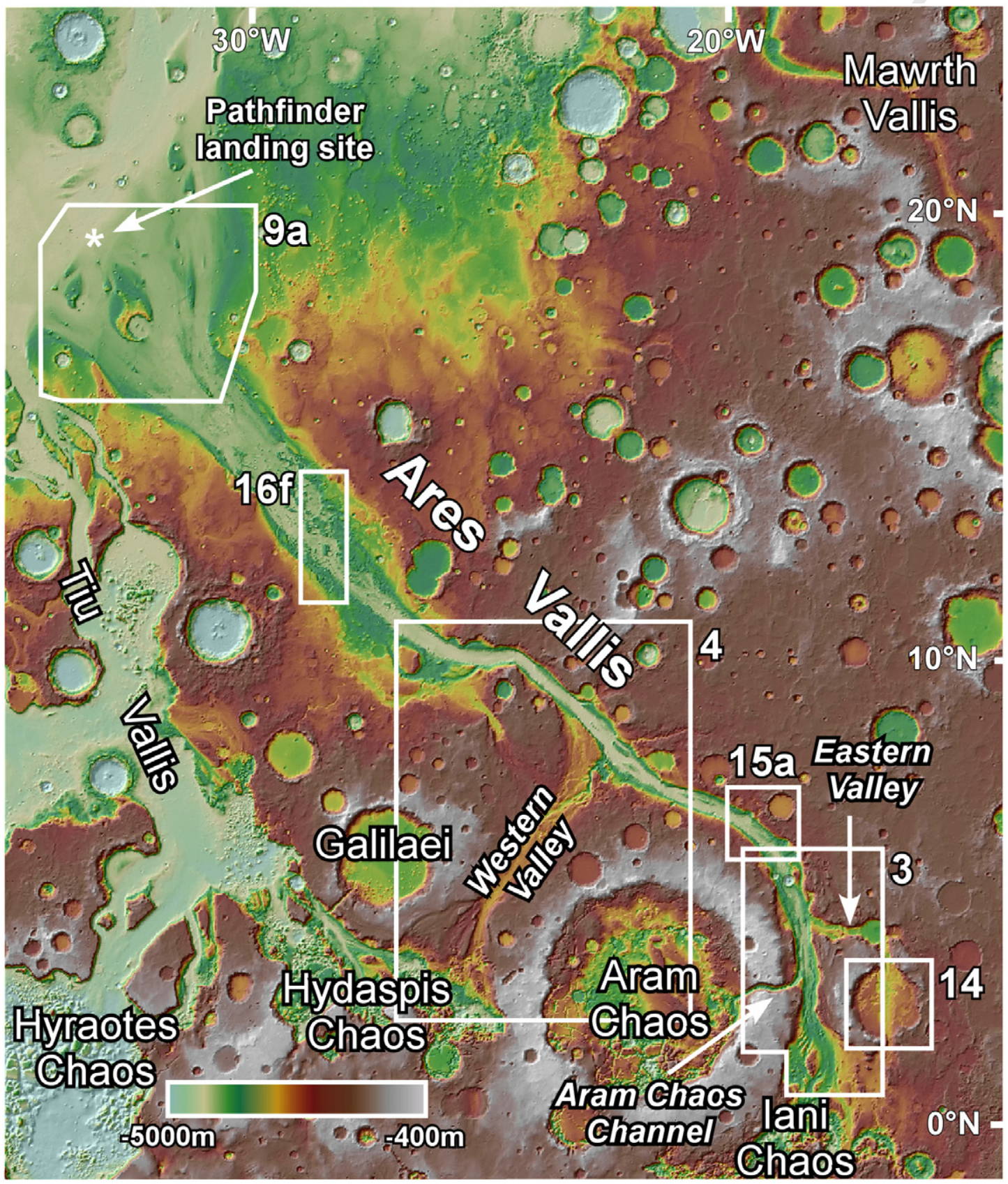




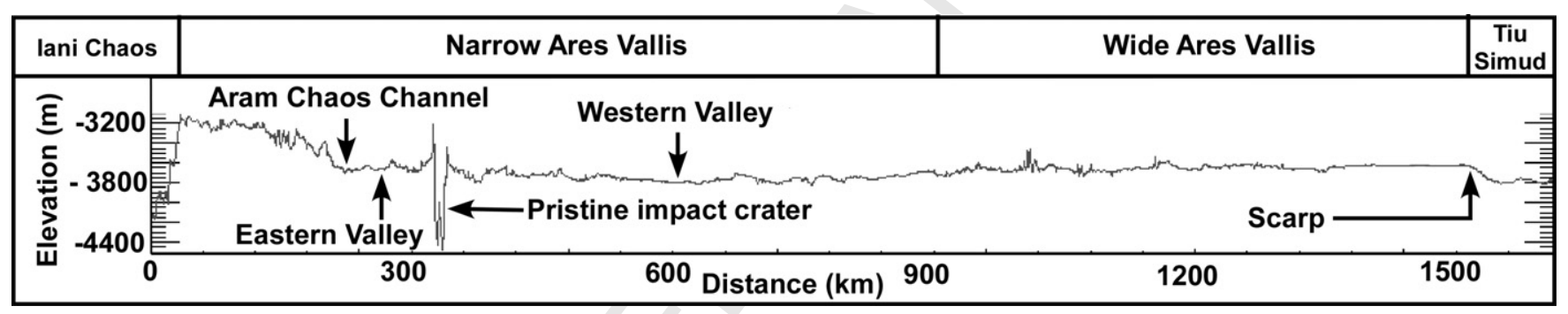



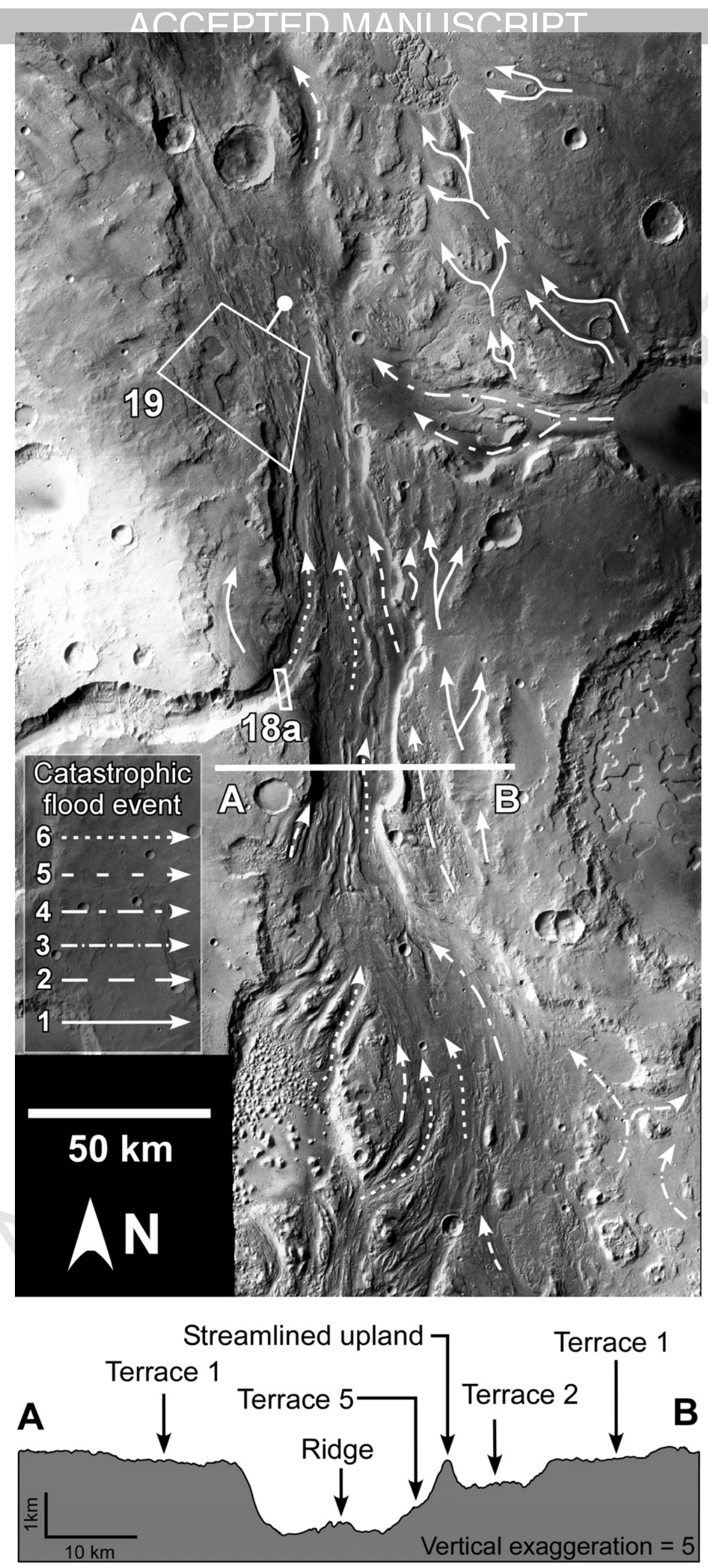


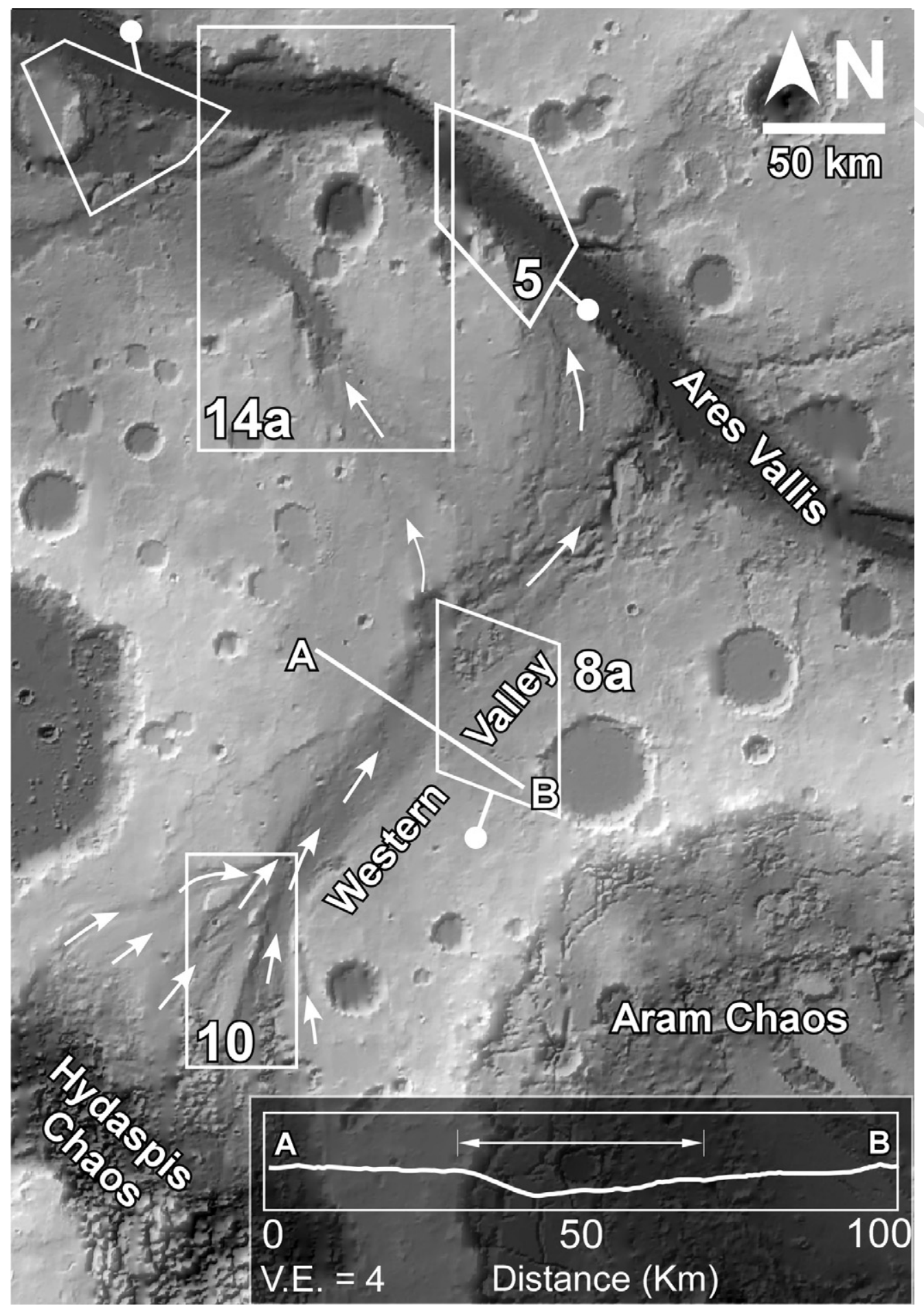



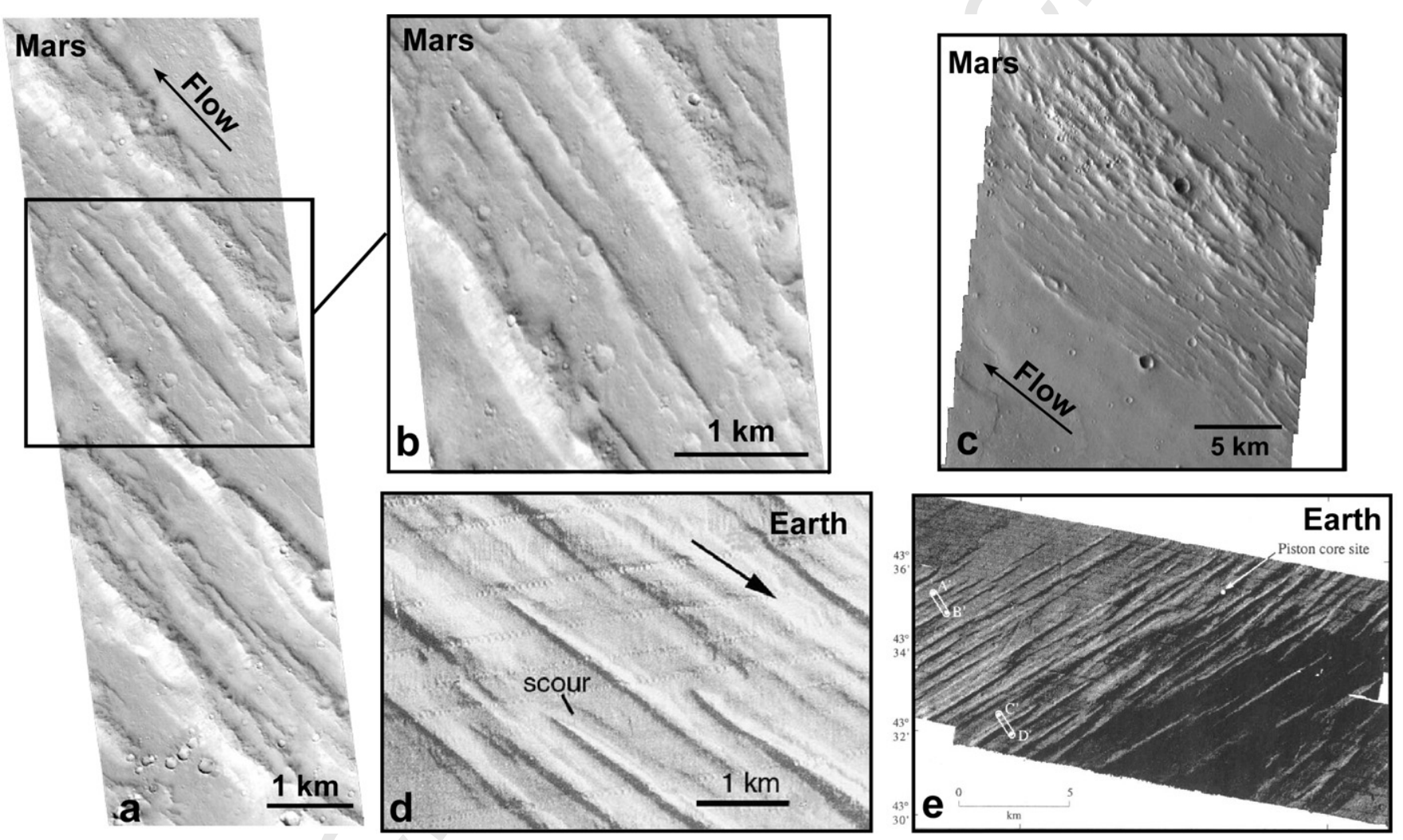

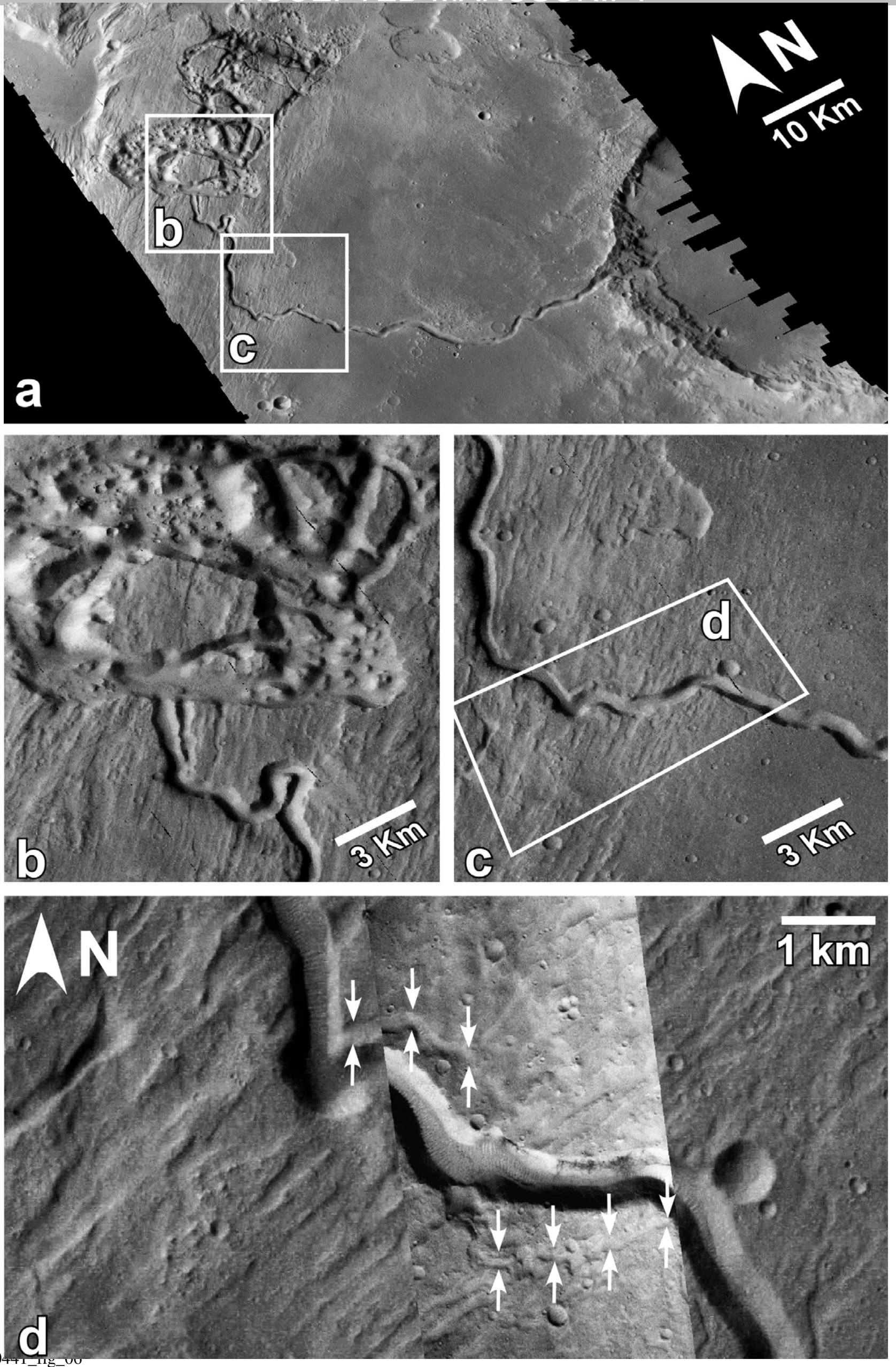

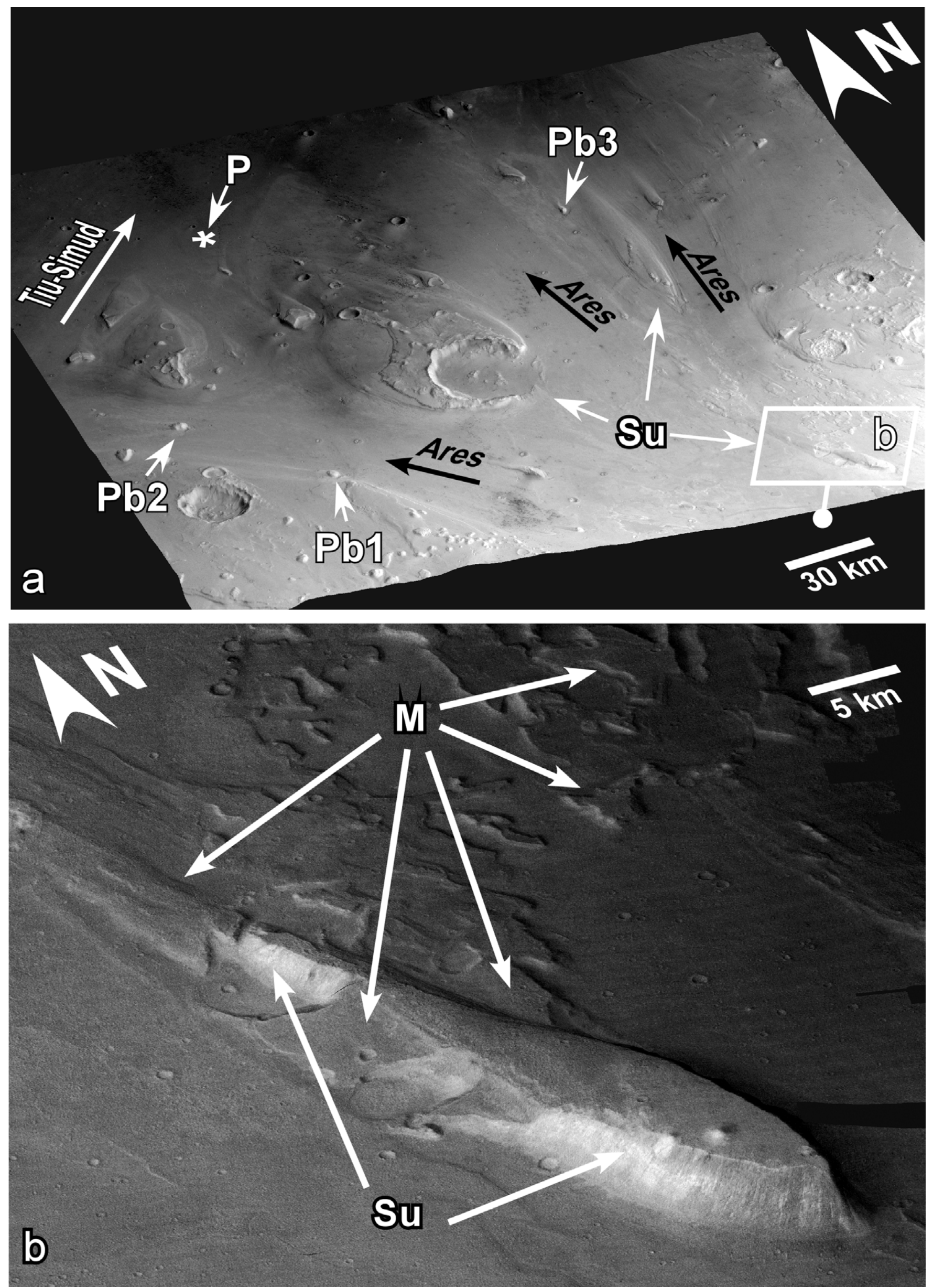

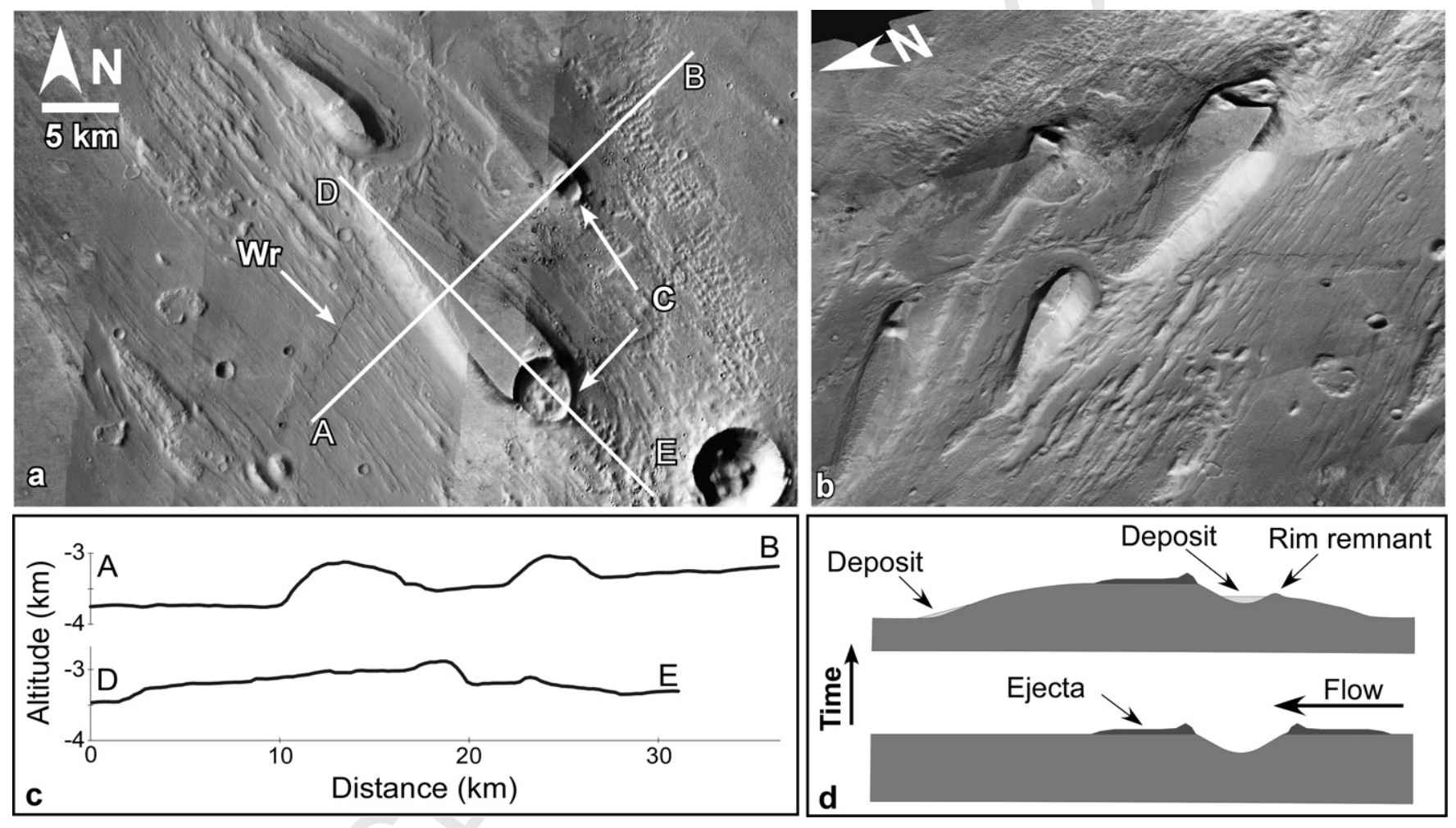


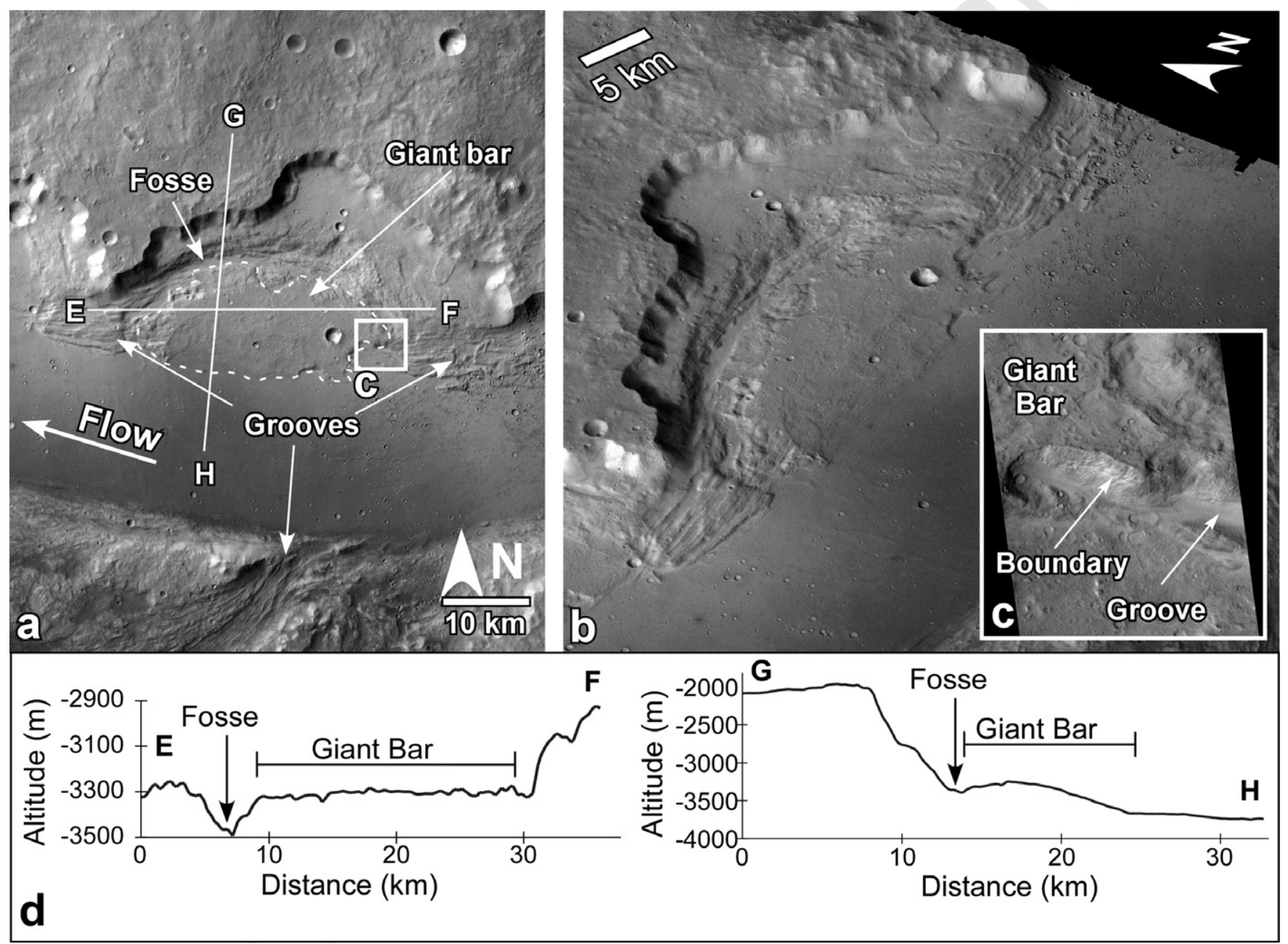



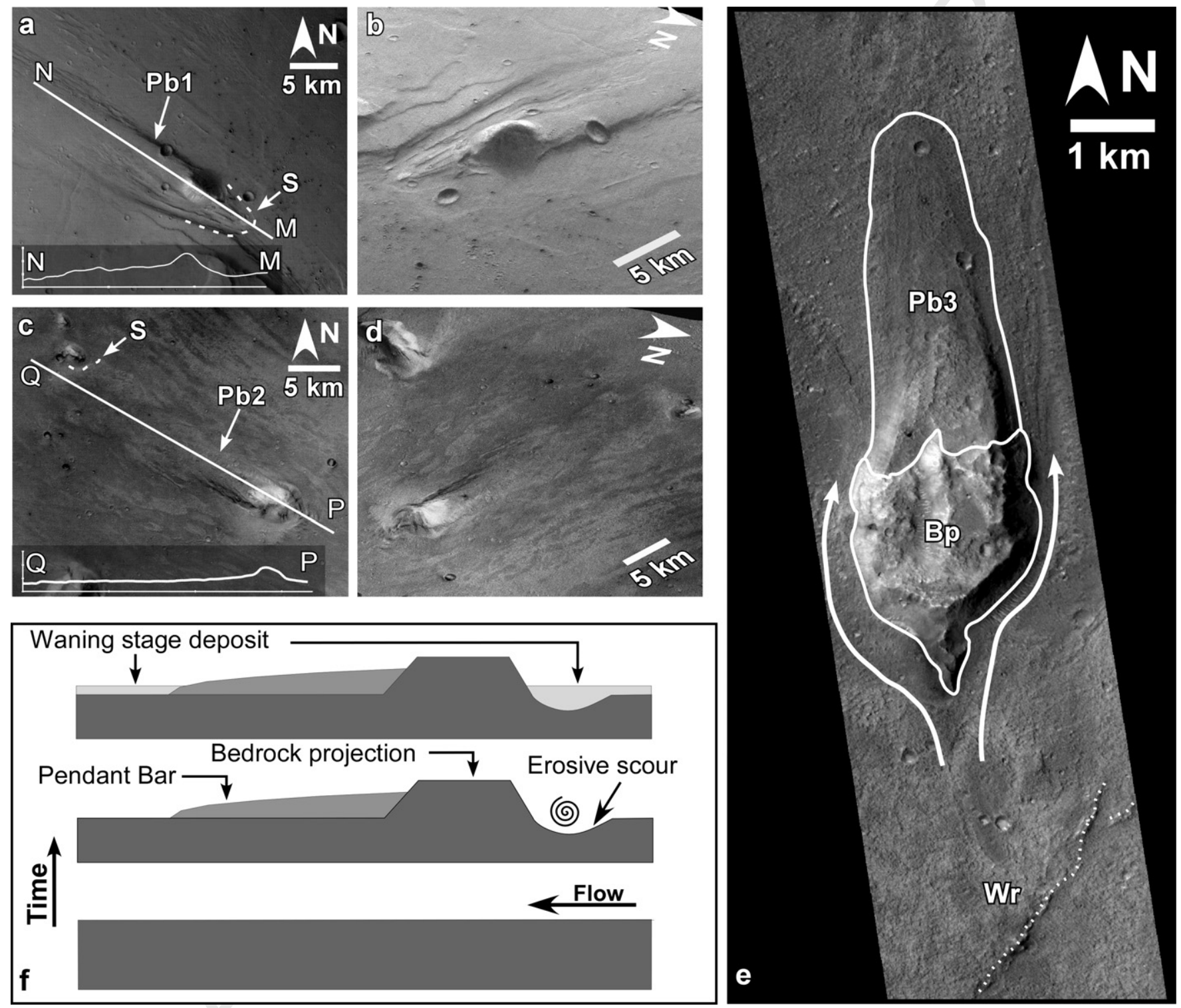

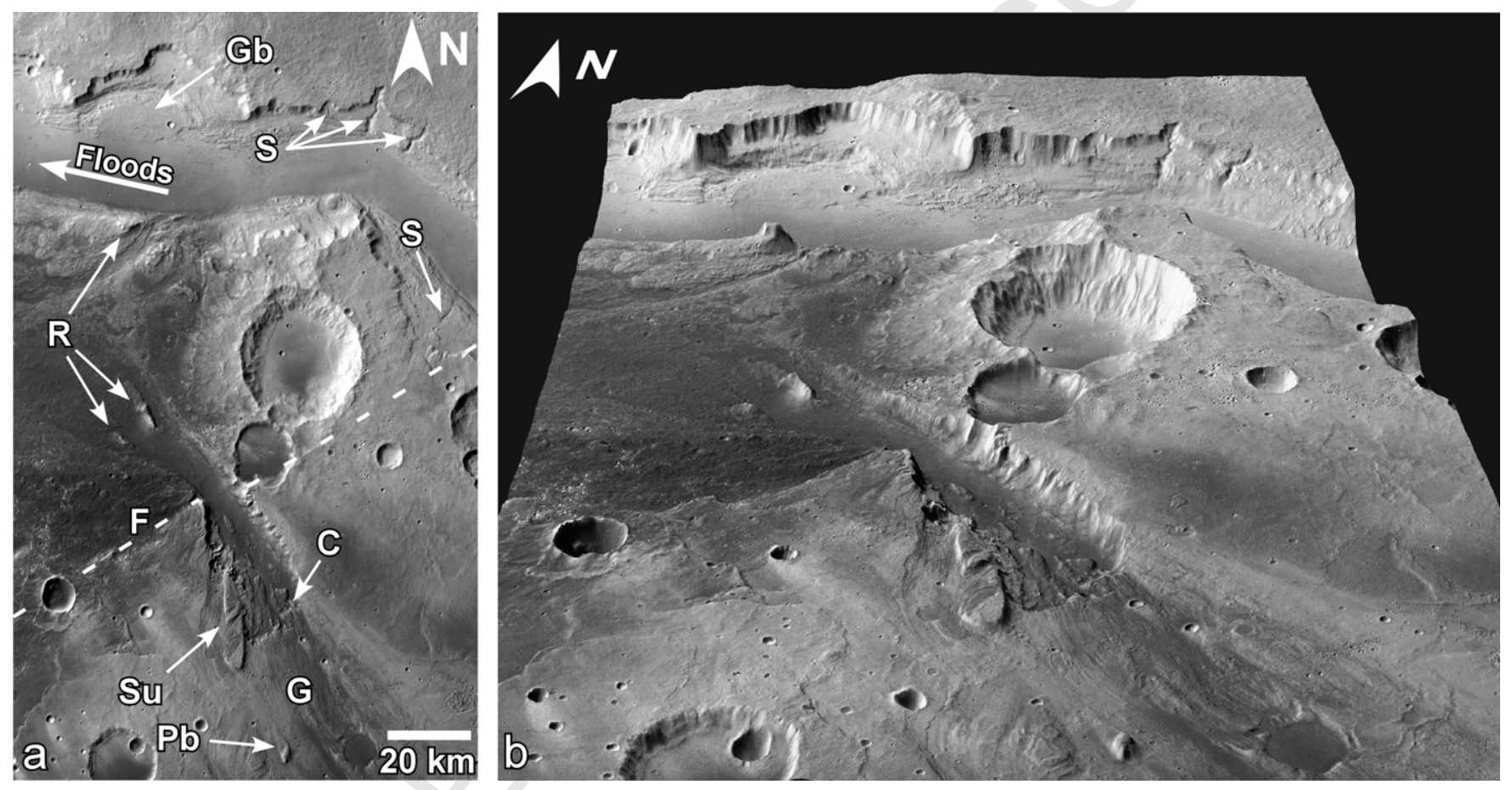

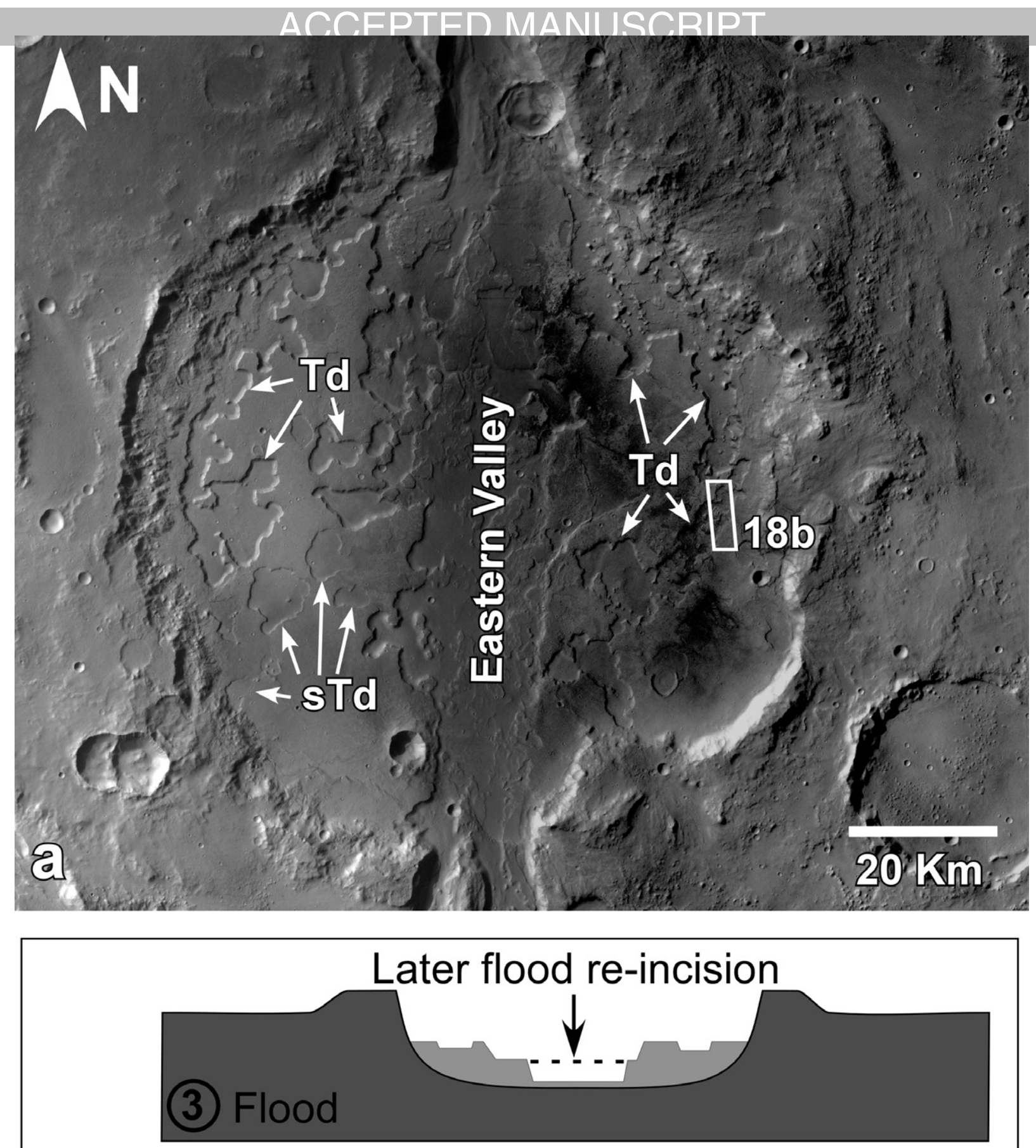

$\stackrel{\Phi}{E} \uparrow$

Thermokarstic depressions

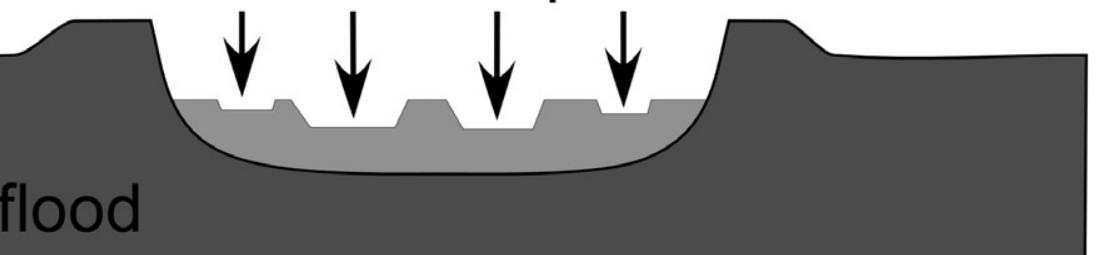

(2) No flood

\section{Earlier flood ice-rich deposit}



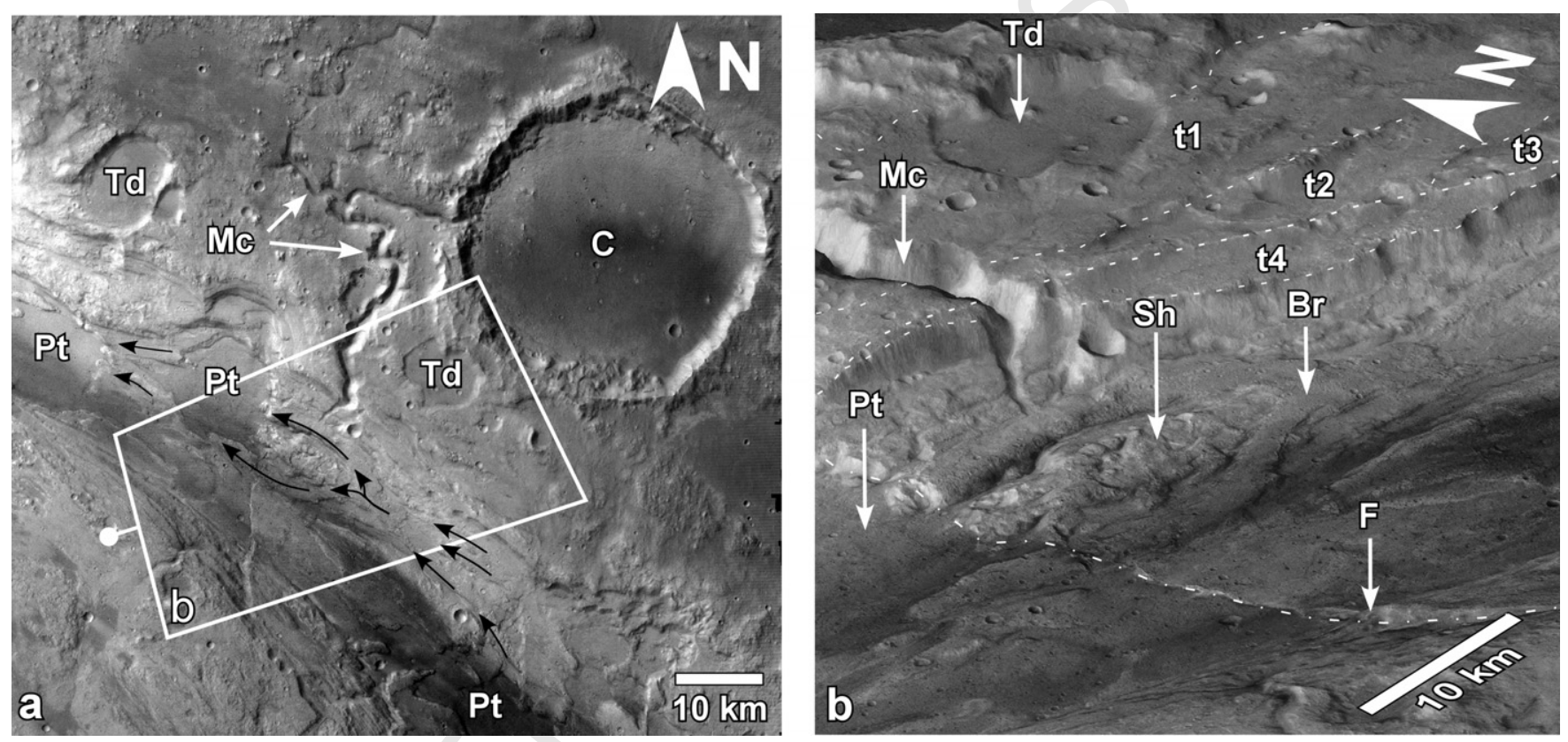

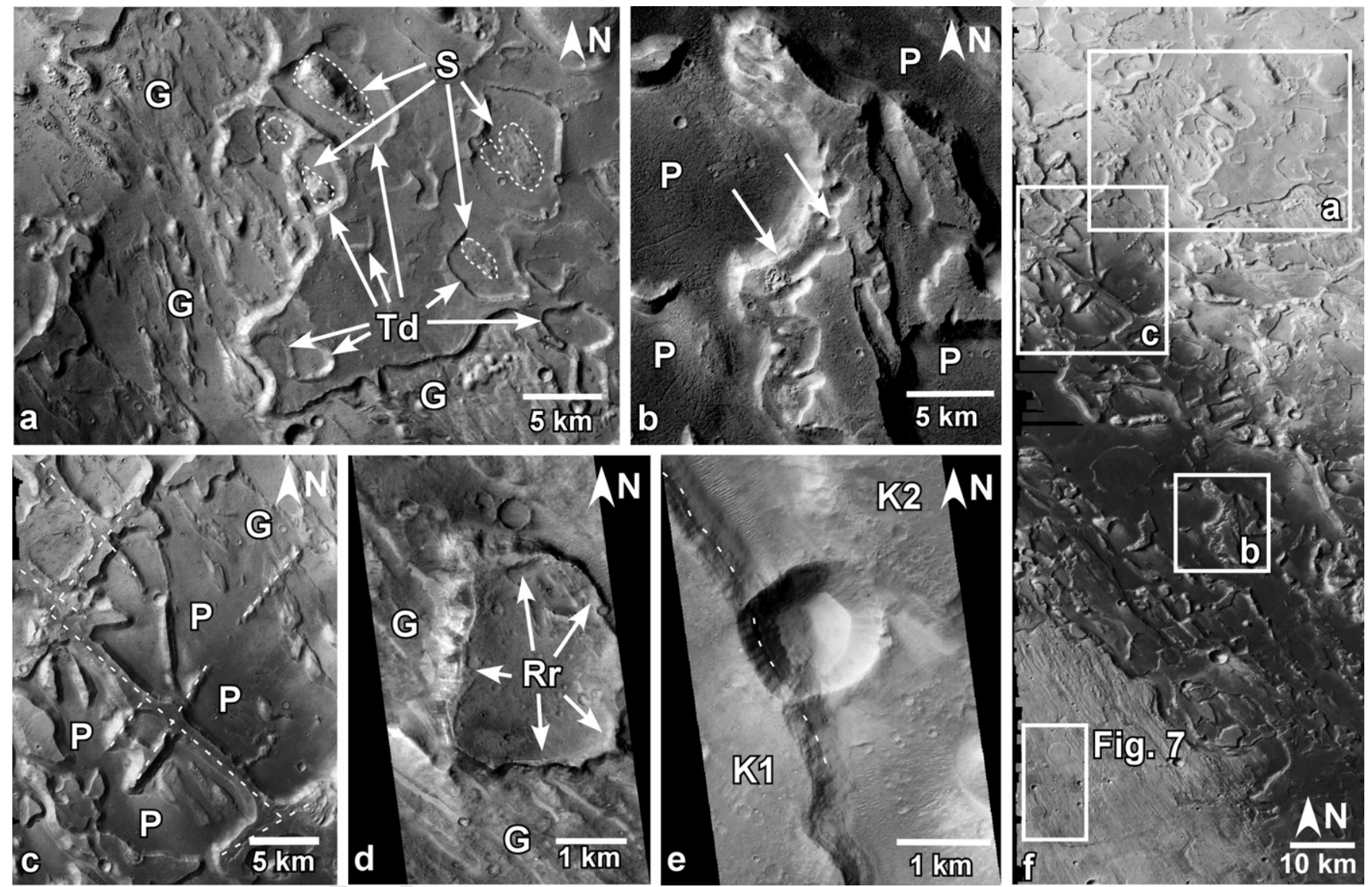


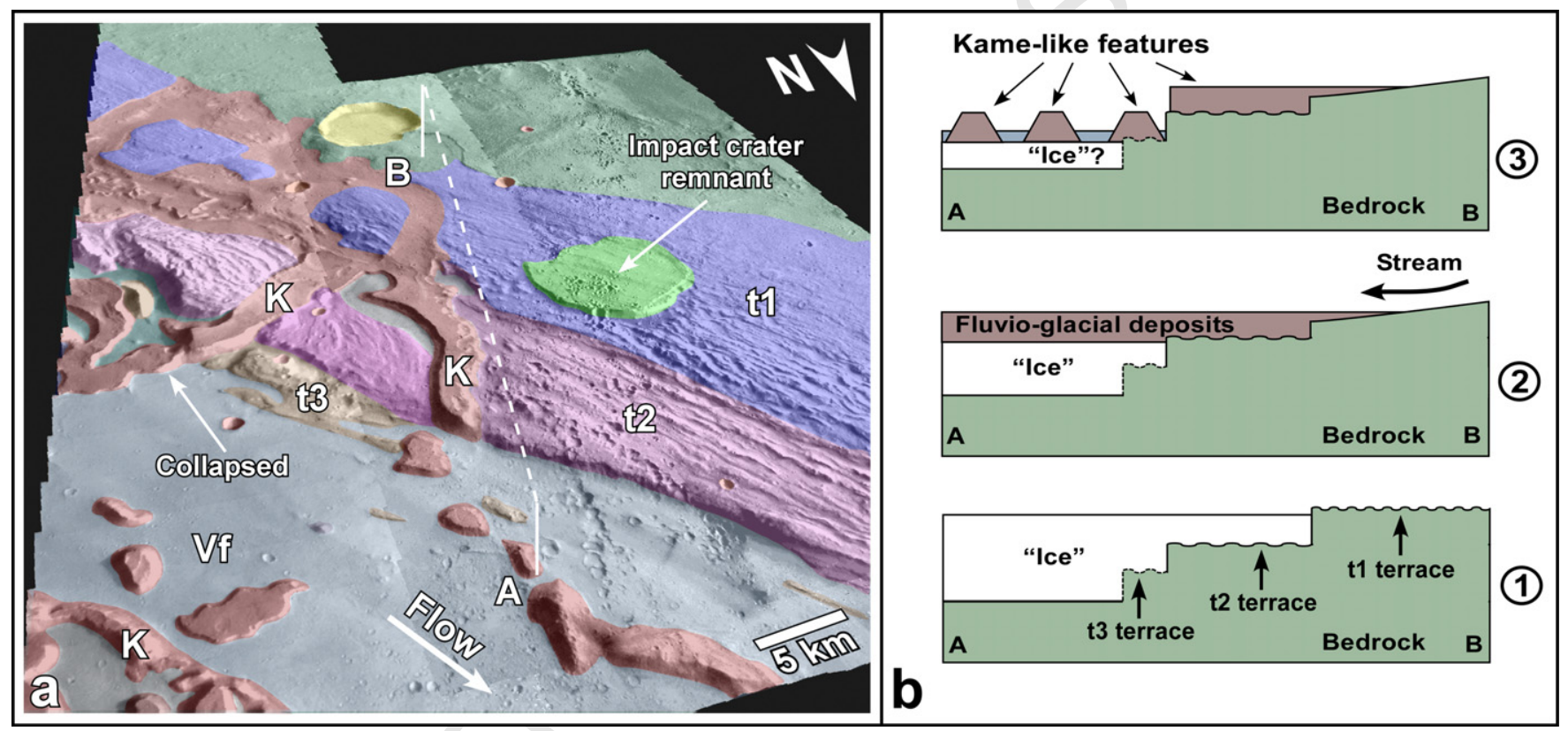




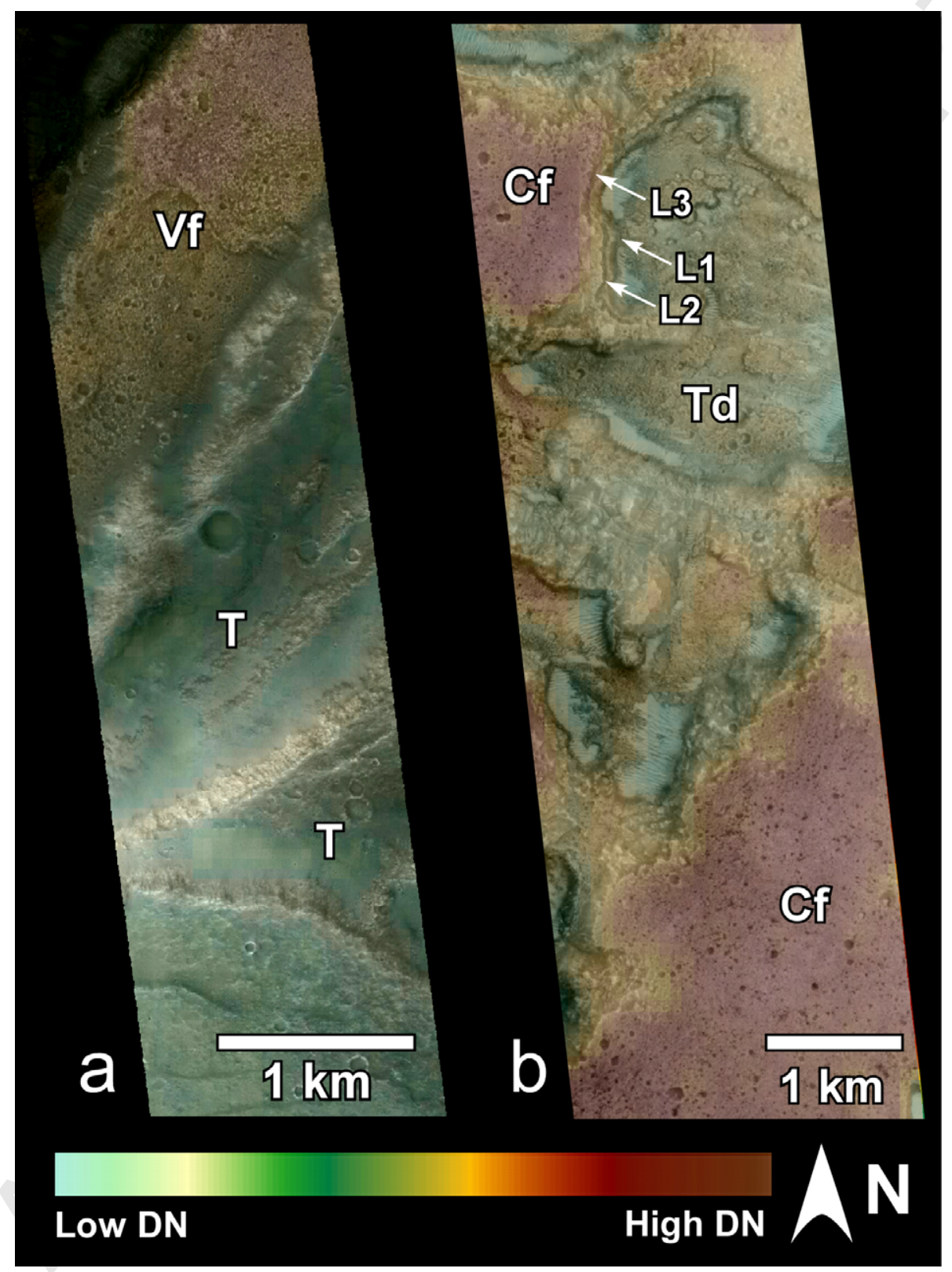




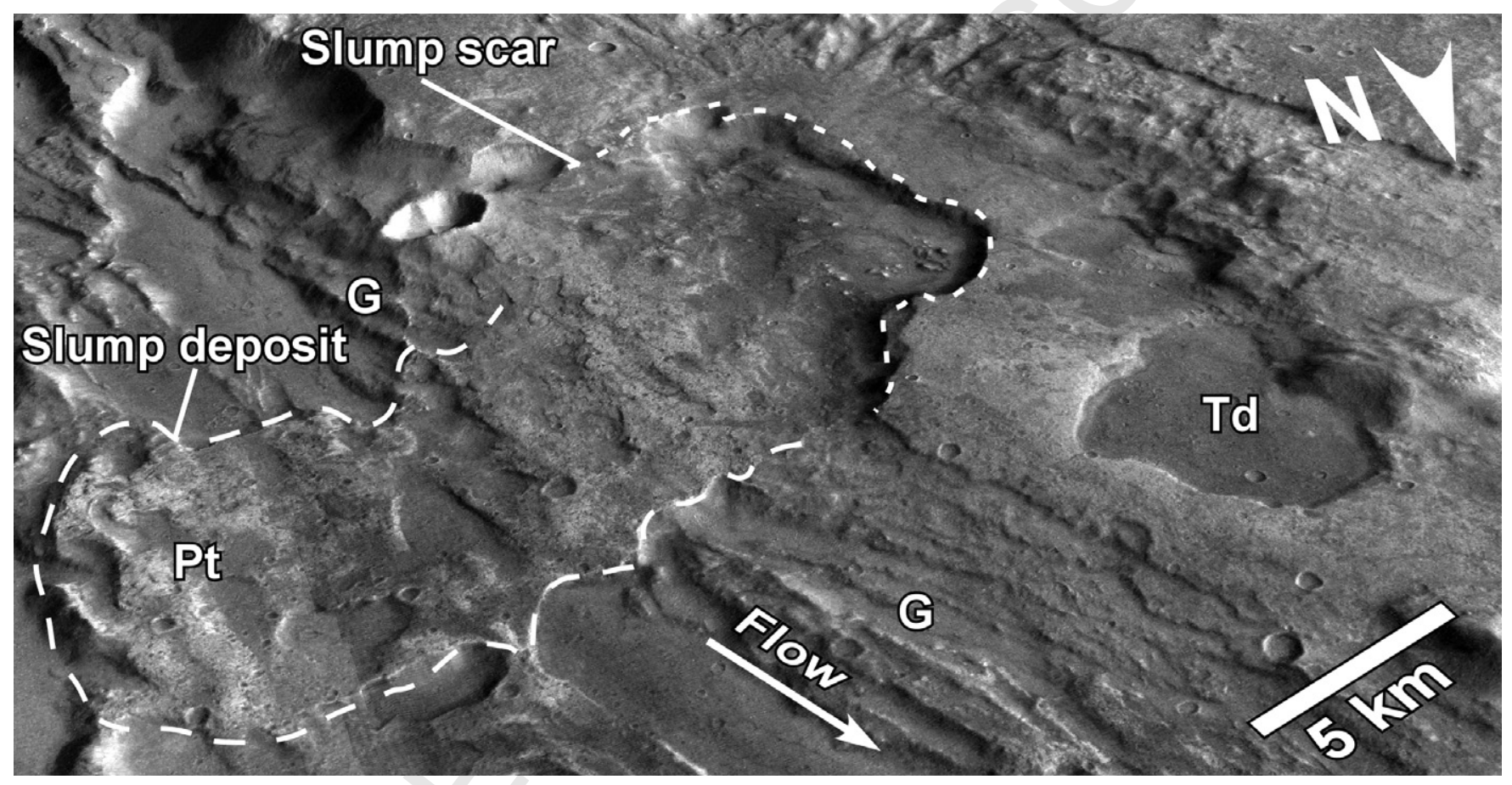




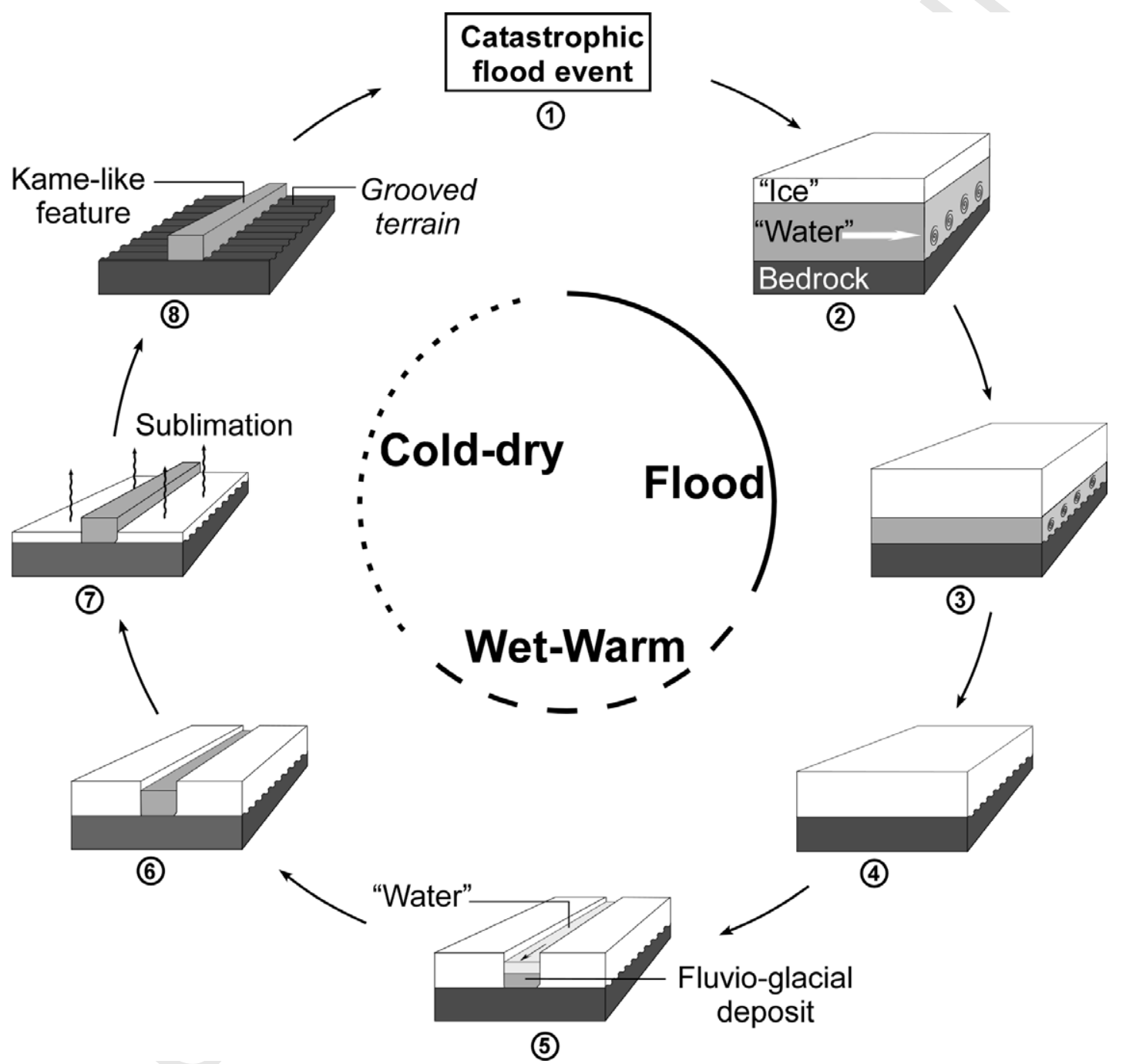

